\title{
REVIEW
}

\section{Production and fate of kelp detritus}

\author{
Kira A. Krumhansl* ${ }^{*}$ Robert E. Scheibling \\ Department of Biology, Dalhousie University, Halifax, Nova Scotia, Canada
}

\begin{abstract}
The flow of detritus between habitats is an important form of connectivity that affects regional productivity and the spatial organization of marine ecosystems. Kelps form highly productive beds or forests that produce detritus through incremental blade erosion, fragmentation of blades, and dislodgement of whole fronds and thalli. Rates of detrital production range from 8 to $2657 \mathrm{~g} \mathrm{C} \mathrm{m}^{-2} \mathrm{yr}^{-1}$ for blade erosion and fragmentation, and from 22 to $839 \mathrm{~g} \mathrm{C} \mathrm{m}^{-2} \mathrm{yr}^{-1}$ for loss of fronds and thalli. The estimated global average rate of detrital production by kelps is $706 \mathrm{~g} \mathrm{C} \mathrm{m}^{-2}$ $\mathrm{yr}^{-1}$, accounting for $82 \%$ of annual kelp productivity. Detrital production rates are regulated by current and wave-driven hydrodynamic forces and are highest during severe storms and following blade weakening through damage by grazers and encrusting epibionts. Detritus settles within kelp beds or forests and is exported to neighboring or distant habitats, including sandy beaches, rocky intertidal shores, rocky and sedimentary subtidal areas, and the deep sea. Exported kelp detritus can provide a significant resource subsidy and enhance secondary production in these communities ranging from tens of meters to hundreds of kilometers from the source of production. Loss of kelp biomass is occurring worldwide through the combined effects of climate change, pollution, fishing, and harvesting of kelp, which can depress rates of detrital production and subsidy to adjacent communities, with large-scale consequences for productivity.
\end{abstract}

KEY WORDS: Kelp bed $\cdot$ Kelp forest $\cdot$ Connectivity $\cdot$ Detritus $\cdot$ Resource subsidy $\cdot$ Local-regional productivity Resale or republication not permitted without written consent of the publisher

\section{INTRODUCTION}

Kelp species have a broad geographic distribution and are a major source of primary production and biogenic habitat in coastal zones of temperate and polar oceans worldwide (Dayton 1985a, Steneck et al. 2002). Kelp productivity is tightly linked to seawater nutrient concentrations (Chapman \& Lindley 1980, Gagné et al. 1982), which are regulated by oceanographic processes. Kelps support high secondary productivity in rich and diverse communities of invertebrates, fish, and mammals, including many commercially important species. The sensitivity of kelps to environmental change and increasing fishing pressure is altering kelp productivity and biomass, which can have important follow-on effects on secondary production and ecosystem function both within kelp beds or forests (Dayton et al. 1992, Steneck et al. 2002) and in adjacent communities that receive kelp detritus.

There is growing recognition that the exchange of detritus is an important form of connectivity among coastal habitats that can influence spatial patterns of primary and secondary productivity (Polis et al. 1997, Loreau et al. 2003, Marczak et al. 2007), and that a significant proportion of energy produced in macrophyte communities enters detrital pathways (Mann 1988, Cebrian 1999). Kelps continuously produce detritus, which is either consumed or decomposed within kelp beds or forests, or exported. Various studies show that kelp detritus is an important resource in adjacent communities (Duggins et al. 
1989, Bustamante et al. 1995, Dugan et al. 2003, Vanderklift \& Wernberg 2008), however, a comprehensive understanding of the nature and extent of this subsidy is lacking. Although the production and fate of detritus have been reviewed for other marine macrophyte communities (e.g. seagrass beds: Mateo et al. 2006, Heck et al. 2008; mangrove forests: Kristensen et al. 2008), reviews of kelp ecosystems provide only a cursory description of detrital pathways (Dayton 1985a, Steneck et al. 2002). Other reviews consider detrital production and processing in terrestrial and aquatic ecosystems more broadly, without specific emphasis on kelp communities (Mann 1988, Cebrian \& Lartigue 2004). The impact of anthropogenic pressures on kelp detrital production and export has not been considered.

In this review, we summarize estimates of detrital production from kelp populations worldwide for comparison with other macrophyte communities that contribute detritus to coastal habitats. We identify environmental and biological factors that regulate the rate of kelp detrital production and degradation, and examine the consequences of detrital kelp subsidies for community organization and productivity in a variety of marine habitats, including sandy beaches, rocky intertidal shores, rocky and sedimentary subtidal areas, and the deep sea. Finally, we discuss anthropogenic impacts on kelp ecosystems that are causing declines in kelp biomass, and highlight the broader implications of these declines for communities subsidized by kelp detritus.

\section{PRODUCTION OF KELP DETRITUS}

There are 3 morphological groupings of kelp species: canopy, stipate, and prostrate (Dayton 1985a, Steneck et al. 2002). All kelps are attached to the substrate by a root-like structure known as a holdfast. Canopy kelps have flexible stems or stipes that are supported by gas-filled bladders called pneumatocysts. The largest of the canopy kelps, the genus Macrocystis, has a primary stipe that gives rise to multiple secondary stipes, each with lateral blades along their extent, referred to as fronds. Other canopy kelps, such as the genus Nereocystis, have a single stipe supported by one large pneumatocyst, from which emanate multiple blades. Stipate kelps typically are smaller and have rigid stipes supporting a single blade, while prostrate kelps are the smallest and have blades that lie directly on the substrate. Stipate and prostrate kelps include the genera Laminaria, Saccharina, Ecklonia, Lessonia, and Eisenia.
Populations of canopy kelps form so-called forests, while prostrate and stipate kelps form beds (Steneck et al. 2002).

Kelp detritus ranges in size from small particles to whole thalli. Whole thalli are lost through breakage at the base of the primary stipe or when holdfasts become detached from the substratum. Frond loss is the result of breakage of the secondary stipe for Macrocystis spp.; individual blades also can detach from secondary stipes with multiple blades. Breakage at the junction of the stipe and blade of prostrate and stipate kelps is another form of blade loss. Loss of whole thalli and blade breakage below the basal meristem prevent re-growth of an individual, and are considered fatal. The distal ends of blades can erode rapidly or gradually, producing detrital fragments that range from small particulates to large sections of blade. Dissolved organic matter is released as kelp blades fragment and erode, and is estimated to account for 16 to $35 \%$ of annual energy production in kelps (Johnston et al. 1977, Hatcher et al. 1977, Mann et al. 1979, Newell et al. 1980).

Rates of dislodgement (including loss of whole thalli and fronds) and erosion (including blade loss and breakage) have been measured (as dry mass or C) for kelp populations spanning the temperate range of kelps worldwide (Fig. 1, Table 1). Although the range of kelps extends into the high Arctic, erosion rate is recorded for only a single population of Laminaria solidungula in the Beaufort Sea, Alaska, USA (Dunton 1984), which was the lowest of all kelp populations studied $\left(26 \mathrm{~g} \mathrm{~m}^{-2} \mathrm{yr}^{-1}, 8 \mathrm{~g} \mathrm{C} \mathrm{m}^{-2} \mathrm{yr}^{-1}\right.$ ). Erosion rate spans 3 orders of magnitude globally, with the highest rate measured for Lessonia spp. in Chile (11071 $\left.\mathrm{g} \mathrm{m}^{-2} \mathrm{yr}^{-1}, 2657 \mathrm{~g} \mathrm{C} \mathrm{m}^{-2} \mathrm{yr}^{-1}\right)$, reflecting the high blade density of these species (2369 to 3019 blades $\mathrm{m}^{-2}$ ) (Tala \& Edding 2007). Erosion rates of Ecklonia spp. were moderately high across all locations, and erosion of Laminaria spp., Saccharina spp., and Macrocystis pyrifera were in the mid to low end of the range. Erosion of Saccharina latissima (formerly Saccharina longicruris, Laminaria longicruris or Laminaria saccharina) (McDevit \& Saunders 2010) was an order of magnitude greater in Nova Scotia, Canada than in Scotland, indicating high variability among populations of the same species in different geographic locations. Erosion rate of a cultured population of Undaria pinnatifida in northern Japan $(9 \mathrm{~g}$ $\mathrm{m}^{-2} \mathrm{yr}^{-1}, 3 \mathrm{~g} \mathrm{C} \mathrm{m}^{-2} \mathrm{yr}^{-1}$ ) was lower than all naturally occurring kelp populations worldwide (Table 1).

Across all populations, erosion accounted for 17.3 to $111.3 \%$ of annual primary productivity (Table 1). Although erosion rate was highest for Lessonia spp. 


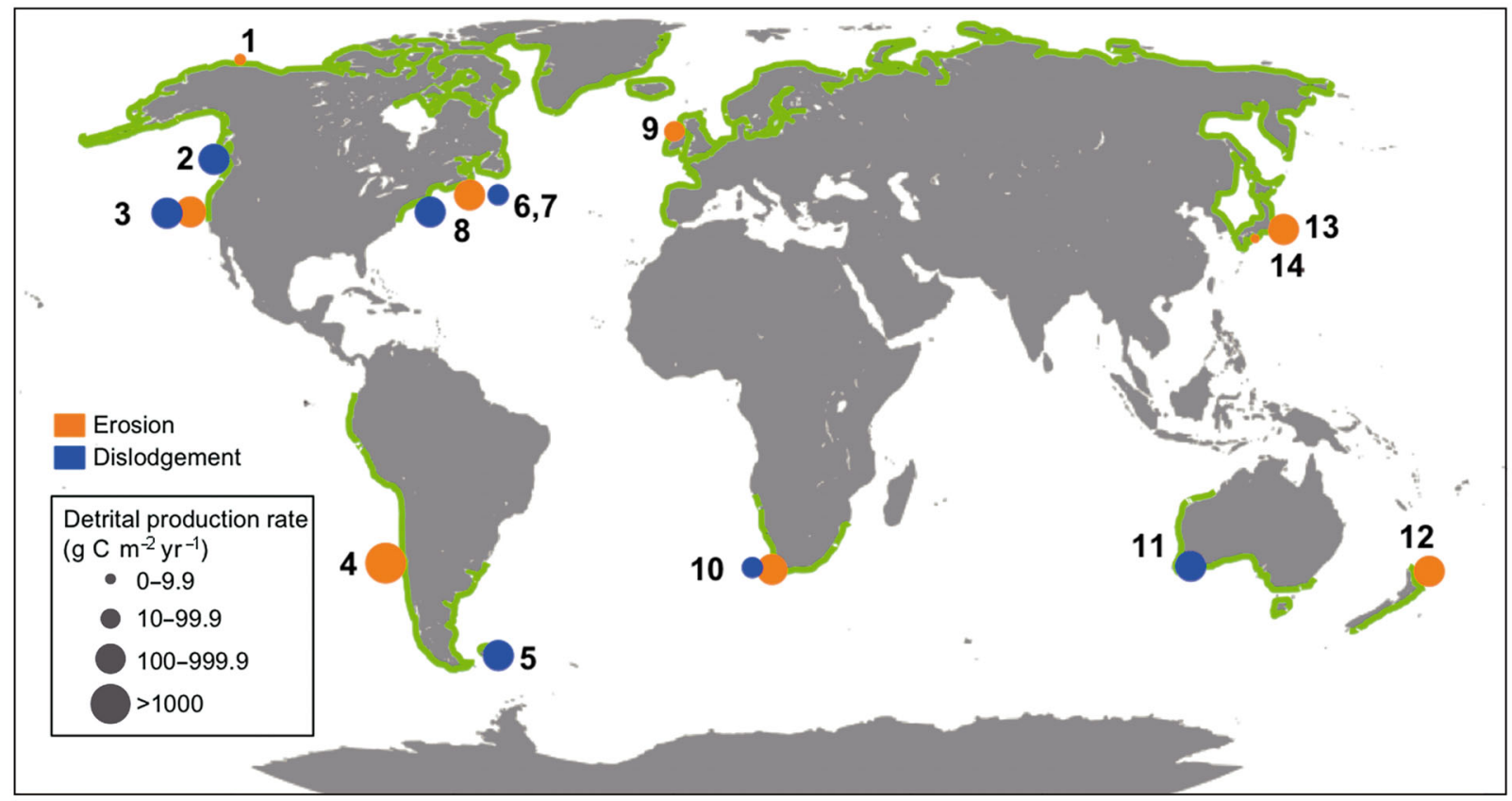

Fig. 1. Global distribution of kelps (green shading) and locations (numbered) where rates of kelp production, erosion (orange circles) and dislodgement (blue circles) have been measured (Table 1). Circle area represents the magnitude of measured rates; overlapping circles indicate locations where erosion and dislodgement rates were measured simultaneously

in Chile, the amount of material eroded accounted for less than half $(47.3 \%)$ of annual primary production. In contrast, Ecklonia cava in southern Japan had the second highest erosion rate $\left(2547 \mathrm{~g} \mathrm{~m}^{-2} \mathrm{yr}^{-1}\right.$, $774 \mathrm{~g} \mathrm{C} \mathrm{m}^{-2} \mathrm{yr}^{-1}$ ) but $91 \%$ of biomass produced annually was eroded. Annual erosion exceeded production for populations of Laminaria digitata and Saccharina latissima in Nova Scotia, indicating that the standing biomass of these species decreased over the measurement period.

Few studies document dislodgement rates for kelp populations (Table 1). Interestingly, measurements from populations of Laminaria digitata and Saccharina latissima in 2 separate locations represented the minimum (Nova Scotia, Canada) and maximum (Rhode Island, USA) rates of the range recorded ( 74 to $2798 \mathrm{~g} \mathrm{~m}^{-2} \mathrm{yr}^{-1}, 22$ to $839 \mathrm{~g} \mathrm{C} \mathrm{m}^{-2} \mathrm{yr}^{-1}$ ). Dislodgement accounted for 6.2 to $49.0 \%$ of annual productivity, which is lower than the range presented for erosion. Only 2 studies have simultaneously measured erosion and dislodgement rates in a single kelp population (Gerard 1976, Newell et al. 1982). For Macrocystis pyrifera, dislodgement rate $(50 \%$ of annual production) was an order of magnitude greater than erosion rate (17\%) (Gerard 1976). The opposite was observed for populations of Laminaria pallida and Ecklonia maxima in South Africa, where dislodgement accounted for a small portion of biomass pro- duced annually (6\%) compared to erosion (70\%) (Newell et al. 1982). Erosion rate also exceeded dislodgement rate in populations of Laminaria digitata and Saccharina latissima measured in 2 separate studies in Nova Scotia (Chapman 1984, Krumhansl \& Scheibling 2011a), and Ecklonia radiata in northern New Zealand and Western Australia (Novaczek 1984, Hatcher et al. 1987). The relative importance of erosion and dislodgement to detrital production may be related to kelp morphology, with larger canopyforming kelps producing more detritus through dislodgement than smaller canopy-forming and prostrate kelps. Spatial and temporal variation in physical processes that cause dislodgement also may account for differences in the relative importance of dislodgement among kelp populations. Erosion is likely to be greater than dislodgement rate in areas less prone to physical disturbance, or during periods when disturbance events are less frequent.

\section{FACTORS REGULATING PRODUCTION OF KELP DETRITUS}

Kelp detritus is produced through wave and current-driven water motion. Losses of kelp biomass through dislodgement and erosion are greatest during storms that generate high flow rates (Gerard 


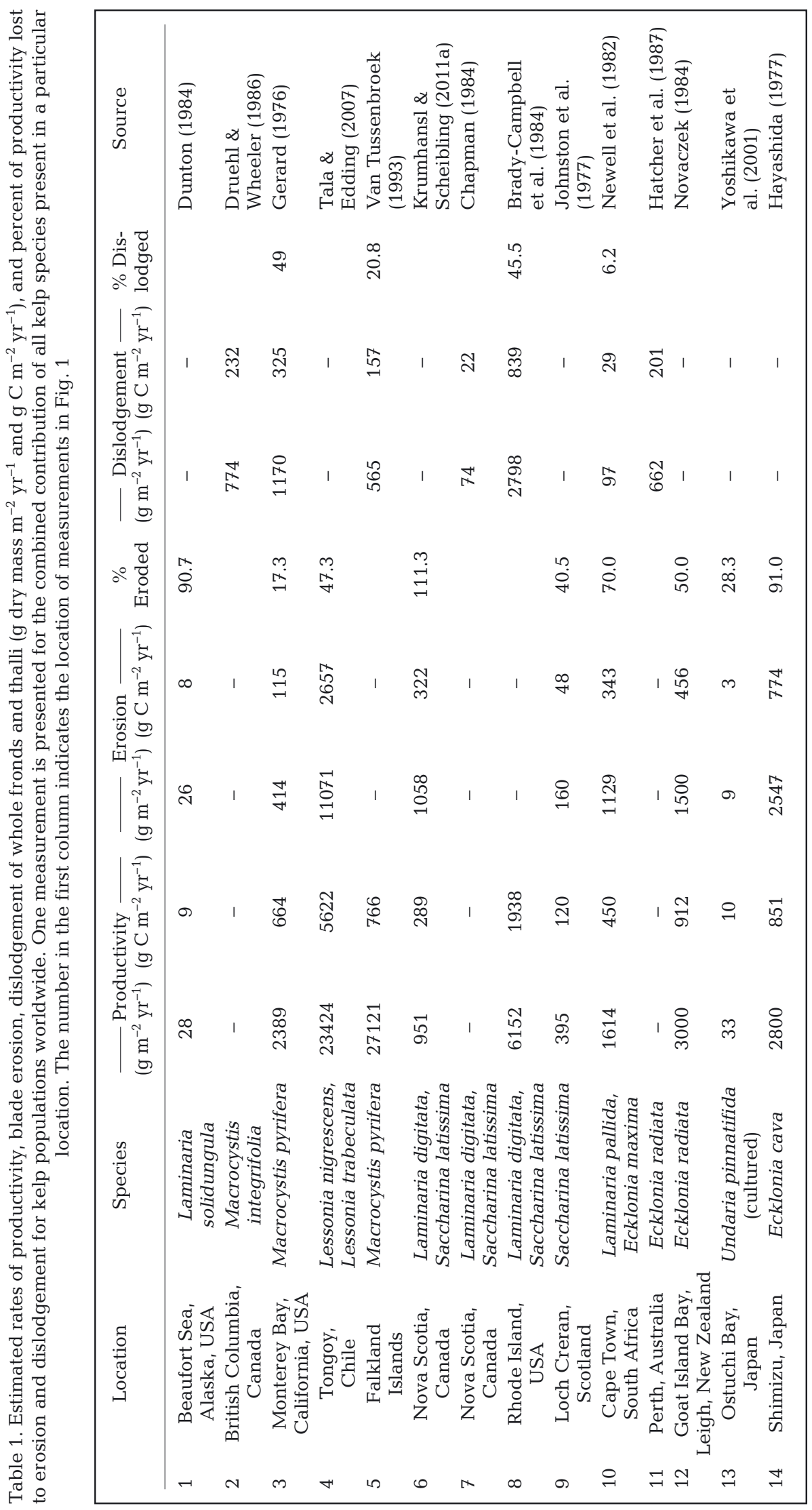

1976, Lüning 1979, Gunnill 1985, Witman 1987, Seymour et al. 1989, Reed et al. 2008, Cavanaugh et al. 2011, Filbee-Dexter \& Scheibling 2012). During periods when maximum wave heights exceed $2.5 \mathrm{~m}$, as much as $30 \%$ of thalli and fronds of Macrocystis pyrifera are lost (Gerard 1976), and losses of density, biomass, and kelp cover can range from 40 to $100 \%$ during the largest wave events ( 5 to $15 \mathrm{~m}$ maximum wave height) (Ebeling et al. 1985, Seymour et al. 1989, Reed et al. 2008). Detached fronds and thalli may become entangled with attached kelps, causing substantial increases in drag that lead to further dislodgement (Gerard 1976, Seymour et al. 1989, Brown et al. 1997). Poorly attached kelps, and those that have settled on small cobbles and biogenic structures such as mussels, are more likely to become dislodged from the substratum at higher flow rates (Gunnill 1985, Witman 1987, Scheibling \& Gagnon 2009). Erosion occurs continuously, even during relatively calm conditions (Reed et al. 2008, Krumhansl \& Scheibling 2011a). Loss of fronds and blade area may actually increase the survivorship of kelps in strong flow by reducing drag on thalli (Gunnill 1985, Thomsen \& Wernberg 2005).

The importance of hydrodynamic forces in determining kelp survivorship and biomass is corroborated by morphological variation in kelps along spatial gradients of wave and current exposure. Kelps in areas of high flow are typically more streamlined or strap-like, less crenulated or undulate, have thicker stipes and blades, and are more firmly attached at the holdfast than kelps in low-flow environments (Gerard \& Mann 1979, Koehl et al. 2008, Wernberg \& Vanderklift 2010, Miller et al. 2011). Never- 
theless, dislodgement and erosion are typically greater at sites with high wave exposure than at more protected sites (Duggins et al. 2003, Krumhansl \& Scheibling 2011a). The measured force to break kelp stipes and blades often exceeds the predicted hydrodynamic force acting on kelps (Utter \& Denny 1996, Denny et al. 1997, Mach et al. 2007), suggesting that breakage and dislodgement are uncommon. For example, Utter \& Denny (1996) showed that the breaking strength of stipes of Macrocystis pyrifera $(2.82 \mathrm{MPa})$ greatly exceeds the stress experienced by stipes (0.04 to $0.68 \mathrm{MPa}$ ) under normal wave conditions ( 0.85 to $2.71 \mathrm{~m}$ significant wave height). Thomsen \& Wernberg (2005) calculated a mean dislodgement force of $93.5 \mathrm{~N}$ for 48 populations of kelp encompassing 10 species. The actual hydrodynamic force acting on kelps is dependent on the size, shape, and buoyancy of macroalgal thalli (Denny 2006), and therefore is species- and location-specific. However, in situ measurements of these forces on kelps are lacking.

High erosion and dislodgment rates occur as a result of damage to kelp holdfasts, stipes, and blades. Fatigue from repetitive loading, abrasion, epiphytism, and grazing generate nicks, holes, and flaws in kelp tissues that concentrate stress when the thallus is in tension, and lead to crack formation and propagation at lower force applications than required to break undamaged tissues (Black 1976, Koehl \& Wainwright 1977, Biedka et al. 1987, Duggins et al. 2001, Krumhansl et al. 2011). For example, grazing damage by snails and sea urchins on kelp stipes and holdfasts is linked to stipe breakage and holdfast dislodgement (Koehl \& Wainwright 1977, Biedka et al. 1987, Duggins et al. 2001). Perforations generated by snails reduce the strength of kelp blade tissues (Black 1976, Krumhansl et al. 2011), which accounts, in part, for seasonal variation in erosion rate (Krumhansl \& Scheibling 2011a) and loss of kelp biomass during storms (Krumhansl \& Scheibling 2011b). Encrustation of kelp blades and stipes by bivalves and bryozoans also increases drag and induces flaws in blade tissues that lead to dislodgement and breakage (Brady-Campbell et al. 1984, Brown et al. 1997, Krumhansl \& Scheibling 2011a, Krumhansl et al. 2011). In particular, encrustation of kelp blades by the bryozoan Membranipora membranacea in its native (Europe) and invaded range (east and west coasts of North America) causes quantifiable reductions in blade strength (Krumhansl et al. 2011), resulting in widespread defoliation of kelp beds during periods of high wave action (Scheibling et al. 1999, Scheibling \& Gagnon 2009).
Water temperature and nutrient availability can affect the quality of kelp blade tissue and, in turn, erosion rate. Low nitrate in summer corresponds to a seasonal minimum in kelp growth rate (Mann 1973, Gagné et al. 1982, Brown et al. 1997). During this period, temperature, irradiance and sedimentation on blades are high (Gunnill 1985, Brown et al. 1997), causing tissue degradation and increasing the susceptibility of blades to breakage (Gunnill 1985, Brown et al. 1997). Older thalli may erode more rapidly than juvenile kelps (Brown et al. 1997, Krumhansl \& Scheibling 2011a).

\section{COMPARISON OF DETRITAL PRODUCTION RATES AMONG MACROPHYTE COMMUNITIES}

The annual rates of erosion and dislodgement averaged among kelp populations measured globally (Table 1) are $448 \pm 455$ (unadjusted mean $\pm 95 \%$ confidence interval) and $257 \pm 206 \mathrm{~g} \mathrm{C} \mathrm{m}^{-2} \mathrm{yr}^{-1}$ respectively. Summing these quantities yields an estimated average detrital production rate of $705 \mathrm{~g} \mathrm{C} \mathrm{m}^{-2} \mathrm{yr}^{-1}$ (Fig. 2). The average productivity of these kelp populations is $864 \mathrm{~g} \mathrm{C} \mathrm{m}^{-2} \mathrm{yr}^{-1}$, indicating that detrital production accounts for the large majority of kelp primary production (81.7\%) (Fig. 2). Similar global estimates of detrital production exist for other macrophyte communities. Seagrass ecosystems produce on average $817 \mathrm{~g} \mathrm{C} \mathrm{m}^{-2} \mathrm{yr}^{-1}$ (including above and below ground production), of which $650 \mathrm{~g} \mathrm{C} \mathrm{m}^{-2} \mathrm{yr}^{-1}$ (79.5\%) enters detrital pathways (Mateo et al. 2006) (Fig. 2).

Mangrove forests contribute a significant amount of detritus in the form of leaf litter to coastal marine communities. Productivity of mangroves $(1788 \mathrm{~g} \mathrm{C}$ $\mathrm{m}^{-2} \mathrm{yr}^{-1}$ ) typically exceeds that of seagrass or kelps, but annual leaf litter estimates $\left(456 \mathrm{~g} \mathrm{C} \mathrm{m}^{-2} \mathrm{yr}^{-1}\right)$ represent only $25.5 \%$ of primary production (Kristensen et al. 2008) (Fig. 2). Salt marshes are also highly productive and produce a significant quantity of detritus annually. Bouchard \& Lefeuvre (2000) estimated productivity of marsh grasses (Pucinellia maritima, Suaeda maritime, Aster tripolium, Salicornia spp., Atriplex portulacoides, Elytrigia aetherica, and Festuca rubra) in France at $4370 \mathrm{~g} \mathrm{C} \mathrm{m}^{-2} \mathrm{yr}^{-1}$, of which $3330 \mathrm{~g} \mathrm{C} \mathrm{m}^{-2} \mathrm{yr}^{-1}$ (76.2\%) entered detrital pathways. Haines (1977) presents a more moderate estimate of detrital production (648 $\mathrm{g} \mathrm{C} \mathrm{m}^{-2} \mathrm{yr}^{-1}$ ) from a salt marsh in Georgia, USA composed of Spartina alterniflora, which is similar to detrital production rates from salt marshes in Argentina composed of S. alterniflora (788 $\mathrm{g} \mathrm{C} \mathrm{m}^{-2} \mathrm{yr}^{-1}$ ) and Spartina densiflora (862 g C m${ }^{-2} \mathrm{yr}^{-1}$ ) (Montemayor et al. 2011). Averaging 

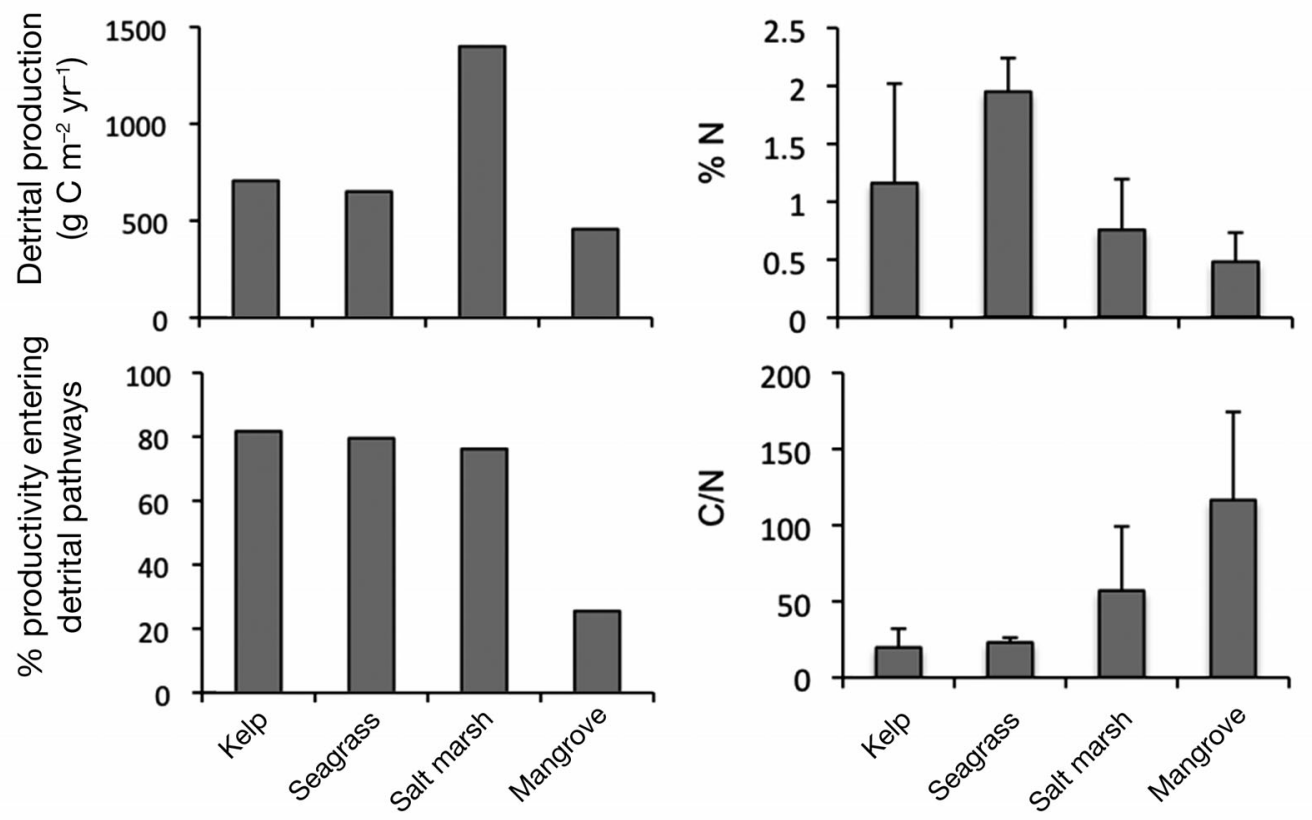

Fig. 2. Average detrital production rates $\left(\mathrm{g} \mathrm{C} \mathrm{m}^{-2} \mathrm{yr}^{-1}\right)$, the percentage of primary productivity entering detrital pathways, the average percentage of nitrogen and $\mathrm{C} / \mathrm{N}$ ratio $(+1 \mathrm{SD})$ for kelp $(\% \mathrm{~N}: \mathrm{n}=184, \mathrm{C} / \mathrm{N}: \mathrm{n}=190)$, seagrass $(\% \mathrm{~N}: \mathrm{n}=770, \mathrm{C} / \mathrm{N}: \mathrm{n}=$ 813), salt marsh ( $\% \mathrm{~N}: \mathrm{n}=37, \mathrm{C} / \mathrm{N}: \mathrm{n}=120)$, and mangrove communities (\% $\mathrm{N}: \mathrm{n}=153, \mathrm{C} / \mathrm{N}: \mathrm{n}=141) . \% \mathrm{~N}$ and $\mathrm{C} / \mathrm{N}$ were calculated from a range of species within each macrophyte type. Kelp sources: Hurd et al. (1994), Henley \& Dunton (1995), Wakefield \& Murray (1998), Van Alstyne et al. (2001), Norderhaug et al. (2003), Dean \& Hurd (2007), Hepburn et al. (2007), Cerda et al. (2009), McDonald \& Bingham (2010), Schaal et al. (2010), Krumhansl \& Scheibling (2012); seagrass sources: Fourqurean et al. (1997), Fourqurean \& Zieman (2002), Touchette et al. (2003), Papadimitriou et al. (2005), Johnson et al. (2006), Smit et al. (2006), Vinther et al. (2008), Campbell \& Fourqurean (2009), Kowalski et al. (2009), Mascaro et al. (2009), MacArthur et al. (2011), Prado \& Heck (2011); salt marsh sources: Buchsbaum et al. (1991), Burke et al. (2002), Dai et al. (2005), Sanmarti \& Menendez (2007), Menendez (2008), Canepuccia et al. (2010), Montemayor et al. (2011), Simoes et al. (2011), Chen et al. (2012), Jimenez et al. (2012); mangrove sources: Giddins et al. (1986), Poovachiranon et al. (1986), Robertson (1988), Camilleri (1989), Rao et al. (1994), Feller et al. (1999), Skov \& Hartnoll (2002), Thongtham \& Kristensen (2005), Nordhaus et al. (2011)

these values yields an estimate of detrital production from salt marsh communities of $1399.5 \mathrm{~g} \mathrm{C} \mathrm{m}^{-2} \mathrm{yr}^{-1}$ (Fig. 2).

Few studies directly quantify detrital production from macroalgal communities other than kelp beds or forests, and these measurements are primarily for other large brown algae. Fucales form extensive beds in intertidal and shallow subtidal habitats, and are often a dominant component of beach wrack (Josselyn \& Mathieson 1980, Yatsuya et al. 2007). Josselyn \& Mathieson (1980) estimated that Ascophyllum nodosum and Fucus vesiculosus in an estuarine system produce detritus at rates of 540 and $414 \mathrm{~g} \mathrm{C} \mathrm{m}^{-2} \mathrm{yr}^{-1}$ respectively, although these estimates were based on wrack deposited on shore. The rate of detrital production from a population of Sargassum muticum in a Danish estuary is estimated at $136 \mathrm{~g} \mathrm{C} \mathrm{m}^{-2} \mathrm{yr}^{-1}$, while Halidrys siliquosa produce substantially less detritus $\left(6.3 \mathrm{~g} \mathrm{C} \mathrm{m}^{-2} \mathrm{yr}^{-1}\right)$ in the same area (Pedersen et al. 2005).

A comparison of these studies indicates that detrital production accounts for a similar percentage of primary production in kelp, seagrass, and salt marsh communities ( 76 to $82 \%$ ) (Fig. 2). This represents the majority of primary production, whereas most of the primary production in mangrove communities accumulates as standing stock biomass (Lugo \& Snedaker 1975, Lee et al. 1990, Kristensen et al. 2008) (Fig. 2). The decomposition rate and ability of organisms to consume plant and algal material is related to its nutritional quality and palatability, specifically to the $\mathrm{C} / \mathrm{N}$ ratio, \% N, content of fibrous material (cellulose, lignin), and concentration of deterrent chemicals (Mann 1988, Cebrian \& Lartigue 2004, Hladyz et al. 2009, Krumhansl \& Scheibling 2012). Based on the $\% \mathrm{~N}$ or $\mathrm{C} / \mathrm{N}$ ratio, kelp on average is more nutritious than salt marsh grass and mangrove leaves (senescent), and less nutritious than seagrass (Fig. 2). Lower consumption, assimilation, and degradation rates of vascular plants relative to kelps and other macroalgae are likely related to a higher content of fibrous material (or lower labile fraction) (Smith \& Foreman 1984, Tenore et al. 1984, Mann 1988, Cebrian 1999, Hladyz et al. 2009). Consumers often 
prefer kelp and other macroalgal detritus to vascular plant detritus (Smit et al. 2006, Doropoulos et al. 2009), and more refractory material accumulates in vascular plant than macroalgal communities (Cebrian \& Lartigue 2004).

\section{DEGRADATION OF KELP DETRITUS}

The rate of kelp degradation depends on the chemical and physical characteristics of detritus, and the environmental conditions under which degradation is occurring. Degradation occurs more rapidly at higher water temperatures (Bedford \& Moore 1984, Rothausler et al. 2009), and under high flow conditions where mechanical breakdown occurs (Tenore et al. 1984, Alkemade \& van Rijswijk 1993). Physical processes also play a role in regulating the environmental conditions within detrital accumulations. Resuspension exposes a greater surface area of detritus to microbial colonization (Stahlberg et al. 2006) and increases the concentration of dissolved oxygen (Tenore et al. 1984, Kristensen 1994, Okey 1997, 2003). Smaller detrital particles degrade at a faster rate than larger fragments because they have a higher surface area relative to their volume for microbial colonization (Smith \& Foreman 1984). Microbial respiration is reduced when algal material is dried onshore, resulting in slower degradation rates compared to wet material (Newell et al. 1985).

Nutritional quality increases throughout the course of kelp degradation (Smith \& Foreman 1984, Mann 1988, Duggins \& Eckman 1997, Norderhaug et al. 2003, Krumhansl \& Scheibling 2012). Microbial colonization and transformation increase the $\% \mathrm{~N}$ in kelp tissues, leading to a gradual decrease in the C/N ratio (Mann 1988, Duggins \& Eckman 1997, Norderhaug et al. 2003, Krumhansl \& Scheibling 2012). Phlorotannins occur in varying concentrations among kelp species and are known to deter grazing (Johnson \& Mann 1986, Iken et al. 2009), reduce growth in filter feeders by decreasing assimilation efficiency (Duggins \& Eckman 1997), and deter colonization by microbes (Ragan \& Glombitza 1986). Phlorotannin concentration decreases rapidly during degradation, and the largest increases in nitrogen occur in species that undergo the greatest reduction in phlorotannins (Duggins \& Eckman 1997). Assimilation efficiency, survival, and growth of several species of polychaetes, mussels, scallops, and amphipods are reduced when fed a single diet of fresh kelp, but are enhanced when fed aged kelp particles (Cranford \& Grant 1990, Duggins \& Eckman 1997 ,
Norderhaug et al. 2003). Species with different nutritional preferences and physiological tolerances colonize algal material at varying times over the course of degradation in response to changing environmental conditions and nutritional quality of the detritus (Fauchald \& Jumars 1979, Bedford \& Moore 1984, Okey 2003, Mamouridis et al. 2011, Krumhansl \& Scheibling 2012).

\section{EXPORT OF KELP DETRITUS: PHYSICAL TRANSPORT}

The extent of detrital export from kelp beds and forests and transport to other habitats is regulated by the interaction between physical characteristics of detritus, physical transport processes, topography, and substratum characteristics (Witman et al. 2004, Kotta et al. 2008, Britton-Simmons et al. 2012). The size of detritus influences its settling and resuspension rates across flow velocities (Norton \& Fetter 1981, Watanabe et al. 2009), while buoyancy determines whether detritus is transported at the surface (positive buoyancy), in the water column (neutral buoyancy), or near-bottom (negative buoyancy), where it is subject to different transport mechanisms. Currents are altered by topographic features, such as submarine canyons, sills, embayments, rocky pinnacles, and depressions, which accelerate or decelerate flow and generate eddies and internal waves (Witman et al. 2004). Detrital kelp accumulates on sandy beaches (Stenton-Dozey \& Griffiths 1983, Dugan et al. 2011), in submerged rocky depressions (Witman 1987, Vetter 1995, Britton-Simmons et al. 2012), and in embayments (Vetter 1995, Bustamante \& Branch 1996) where flow is reduced. The movement of detritus across habitat boundaries is influenced by boundary permeability; topographic features (e.g. cliffs) and biogenic structures (e.g. macrophytes) can act as barriers to transport (Witman et al. 2004). The softness and penetrability of the substratum influences the likelihood that detritus is trapped and buried (Kristensen et al. 2008, Montemayor et al. 2011), and substratum roughness increases turbulence in the benthic boundary layer, delivering suspended detrital particles to benthic consumers (Witman et al. 2004).

\section{EXPORT OF KELP DETRITUS: SINKS}

Kelp detritus can settle within kelp beds and forests, where it serves as food for local benthic invertebrates (Dunton \& Schell 1987, Tutschulte \& 
Connell 1988, Norderhaug et al. 2003, Schaal et al. 2009), or be advected to adjacent or distant habitats. The transfer of resources across habitat boundaries plays a central role in shaping ecological patterns and processes (Huxel et al. 2004, Heck et al. 2008, Lamberti et al. 2010). Resource subsidies influence almost all levels of ecology, from behavior (Harrold \& Reed 1985, Rodriguez 2003) and species interactions (Spiller et al. 2010), to productivity (Bustamante \& Branch 1996, Polis \& Hurd 1996), food web stability (Huxel \& McCann 1998, Huxel et al. 2002, Marleau et al. 2010), and population dynamics (Bustamante et al. 1995, Barrett et al. 2005). Nutrients and detritus subsidize lower trophic levels, while carrion and prey subsidize higher trophic levels. Subsidies have a larger effect when they occur at lower trophic levels where species are more specialized than consumers at higher trophic levels (Polis \& Hurd 1996, Huxel \& McCann 1998, Marczak et al. 2007), and when productivity or the amount of an equivalent resource is lower in the recipient community than in the source community (Polis \& Hurd 1996, Marczak et al. 2007). Subsidies can be reciprocal (Nakano \& Murakami 2001); for example, when imported kelp detritus is processed and nutrients are returned to the source kelp bed or forest (Gravel et al. 2010). The proportion of detritus that is exported from kelp beds and forests is unknown, but the consequences of detrital subsidies for recipient populations and communities are documented in a variety of habitats.

\section{Onshore transport and deposition}

\section{Sandy beaches}

Kelp detritus plays a significant role in shaping community dynamics on sandy beaches, and is perhaps the most well-known example of kelp detrital subsidy to an adjacent community. Sandy beaches have very low local primary productivity (0 to $50 \mathrm{~g} \mathrm{C}$ $\mathrm{m}^{-2} \mathrm{yr}^{-1}$; Brown 1964, Munro et al. 1978, Griffiths et al. 1983, Colombini \& Chelazzi 2003), largely because sandy sediments are highly mobile and thus unsuitable for attachment by macrophytes or formation of benthic diatom assemblages (Griffiths et al. 1983). Imported detritus is the primary food source for resident fauna and microbes. Rates of kelp deposition (as wet mass) range from 1200 to $2200 \mathrm{~kg} \mathrm{~m}^{-1} \mathrm{yr}^{-1}$ for Laminaria pallida and Ecklonia maxima in South Africa (Koop \& Field 1980, Stenton-Dozey \& Griffiths 1983), from 450 to $548 \mathrm{~kg} \mathrm{~m}^{-1} \mathrm{yr}^{-1}$ for Macrocystis pyrifera in California, USA (Hayes 1974, Dugan et al. 2011), and from 180 to $1450 \mathrm{~kg} \mathrm{~m}^{-1} \mathrm{yr}^{-1}$ for Ecklonia radiata in Western Australia (Hansen 1984). Deposition of kelp detritus varies by season in response to changing water temperatures and wave conditions (Koop \& Field 1980, Stenton-Dozey \& Griffiths 1983). For example, deposition is highest following storms in spring (April-May) and fall (October-November) in Maine, USA (Witman 1987). Kelp is estimated to account for 55 to $66 \%$ of total macrophyte biomass on sandy beaches in California (Lastra et al. 2008, Dugan et al. 2011) and 14 to 52\% in Patagonia (Piriz et. al 2003).

Detrital processing by microbes and meio- and macrofauna on sandy beaches plays a key role in coastal nutrient cycling (Pearse et al. 1942, Dugan et al. 2011). Bacteria and protozoans rapidly colonize detrital kelp deposits on beaches (Fig. 3), causing surficial lesions and cell lysis that release dissolved and particulate organic matter into the sediments (Koop et al. 1982). Carbon in this leachate is converted to microbial biomass and remineralized (Koop et al. 1982), directly absorbed by meiofauna (Koop \& Griffiths 1982, McLachlan 1985), or returned to the sea via tidal forcing or rainwater run-off. Nitrogen in the leachate is rapidly remineralized and nitrified, and accumulated as dissolved inorganic nitrogen (DIN) in sediments beneath kelp deposits (Dugan et

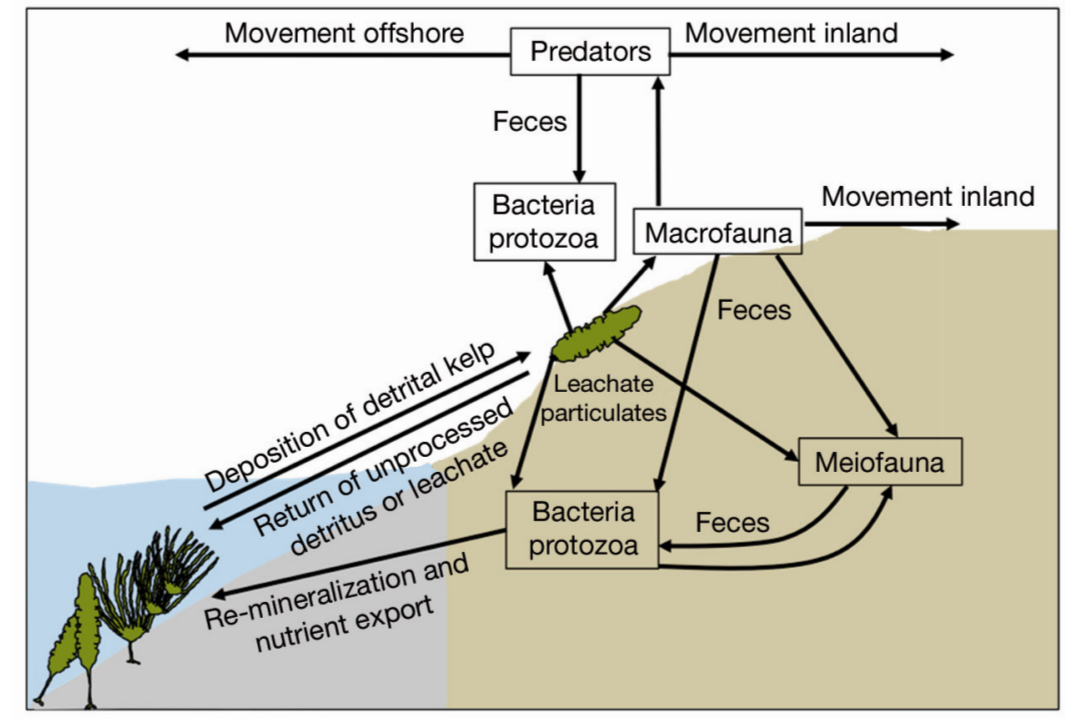

Fig. 3. Energy flow associated with faunal and microbial processing of kelp detritus in sandy beach ecosystems 
al. 2011). Koop et al. (1982) found that very little DIN is returned to the sea following remineralization in beach sands in South Africa. In contrast, Dugan et al. (2011) showed that DIN in surf-zone water in California was positively correlated with DIN in intertidal sediments, suggesting export from beach sediments. Beaches can act as sources or sinks of nitrogen depending on the rate of erosion of beach sediments (Colombini \& Chelazzi 2003, Dugan et al. 2011). Dissolved organic matter (DOM) may also return to the sea before bacterial processing (Dugan et al. 2011).

Deposits of kelp detritus on beaches also are readily colonized by meio- and macrofauna (Hayes 1974, Koop et al. 1982, Griffiths et al. 1983, McLachlan 1985, Inglis 1989, Dugan et al. 2003). Species distributions are tightly linked to kelp deposition, with the highest microbial and faunal abundance, biomass, and diversity occurring in the vicinity of detritus (Griffiths et al. 1983, McLachlan 1985, Dugan et al. 2003). Amphipods, isopods, dipterans, and coleopterans are the predominant macrofaunal consumers of kelp detritus (Griffiths \& Stenton-Dozey 1981, Griffiths et al. 1983, Lavoie 1985, McLachlan 1985, Dugan et al. 2003). Their grazing activity releases particulates, leachates, and fecal pellets (Fig. 3), which stimulate the growth of bacteria and infaunal invertebrates, such as bivalves, nematodes, and oligochaetes (Newell et al. 1982, Griffiths et al. 1983, McLachlan 1985). Meiofauna in sediments directly absorb DOM and consume bacteria associated with kelp leachate and fecal pellets (Griffiths et al. 1983). Invertebrates can consume up to $75 \%$ of the biomass of detrital kelp in some beach systems (Griffiths \& Stenton-Dozey 1981, Griffiths et al. 1983, Lastra et al. 2008), or as little as 5 to $9 \%$ in others (Koop et al. 1982, Inglis 1989), indicating large variability in the importance of these consumers in detrital processing. Macrofauna can slow the process of degradation in some systems by preferentially consuming highly degraded material, which retards microbial colonization and breakdown (Bedford \& Moore 1984). The extent of microbial and meio- and macrofaunal colonization and processing of detritus are determined by the residence time of detrital deposits, which in turn is regulated by physical factors, such as beach morphology, weather, and tides, and characteristics of the detritus (e.g. buoyancy) (Orr et al. 2005). Longterm deposition of kelp detritus may have detrimental effects on species distribution and abundance on beaches by creating areas of anoxia, low $\mathrm{pH}$, or high hydrogen sulfide concentration (McLachlan 1985, Colombini \& Chelazzi 2003), or by providing a physical barrier to burrowing (Soares et al. 1996).
Kelp deposition on beaches and the associated accumulation of meio- and macrofauna attract predators such as birds, carnivorous isopods and coleopterans, crustaceans, and arachnids (Griffiths et al. 1983, Bradley \& Bradley 1993, Anderson \& Polis 1998, Dugan et al. 2003, Mellbrand et al. 2011). Consumption of kelp-associated fauna can account for a significant portion of the diets of these predators (Griffiths et al. 1983, Mellbrand et al. 2011), which then act as vectors for the landward transport of marine-derived material (Anderson \& Polis 1998, Mellbrand et al. 2011). In particular, islands with low terrestrial relative to marine productivity are heavily influenced by the input of marine detritus (Polis \& Hurd 1996, Anderson \& Polis 1998).

\section{Rocky intertidal habitats}

A strong linkage also can occur between subtidal kelp beds or forests and adjacent rocky intertidal communities through the transfer of detritus. While detrital deposition tends to be low in rocky intertidal areas with high wave exposure, deposition on semiexposed and sheltered rocky shores can be substantial (Bustamante et al. 1995, Bustamante \& Branch 1996, Rodriguez 2003). For example, Bustamante et al. (1995) showed that, on average, $960 \mathrm{~g} \mathrm{~m}^{-2} \mathrm{~d}^{-1}$ (wet mass) was deposited in a sheltered rocky bay in South Africa, exceeding local estimates of kelp productivity. Orr et al. (2005) estimated that kelps (Macrocystis integrifolia, Nereocystis luetkeana, and Egregia menziesii) account for 18 to $32 \%$ of macrophyte biomass accumulating on rocky and gravel beaches in British Columbia, Canada.

Invertebrate grazers on rocky shores may depend more on imported kelp detritus than intertidal microand macroalgae (Bustamante et al. 1995, Rodriguez 2003). On the central Chilean coast, sea urchins emerge from cryptic habitats in response to kelp deposition (Rodriguez \& Farina 2001), forming aggregations that rapidly consume detritus (Rodriguez 2003). Sea urchins receiving this subsidy develop larger gonads than those consuming only autochthonous production (Rodriguez 2003). On rocky shores in South Africa, the limpet Patella grenatina traps and consumes detrital kelp when submerged at high tide (Bustamante et al. 1995). Kelp is a major component of the diet of these limpets, whose spatial distribution is correlated with the biomass of deposited kelp (Bustamante et al. 1995). Experimentally restricting access to detrital kelp reduced survival and biomass of limpets, indicating that this subsidy is a major 
determinant of the distribution and abundance of this intertidal grazer (Bustamante et al. 1995).

Particulate detritus produced during erosion of kelp blades is utilized by intertidal and subtidal benthic filter feeders (Bustamante \& Branch 1996, Kaehler et al. 2006). Kelp particulates are the dominant form of particulate organic matter (POM) within kelp beds and forests (Bustamante \& Branch 1996) and can occur in concentrations exceeding that of phytoplankton across an offshore range of $>14 \mathrm{~km}$ (Kaehler et al. 2006). In South Africa, kelp constitutes the largest proportion of the diets of intertidal filterfeeding mussels and barnacles, and spatial variation in filter-feeder biomass is related to near-shore concentrations of particulate kelp (Bustamante \& Branch 1996). Duggins et al. (1989) linked high rates of secondary production in intertidal mussels and barnacles in Alaska to subsidy by nearby subtidal kelps. More recently, Tallis (2009) demonstrated that kelp constitutes 10 to $88 \%$ of the diets of filter feeders inhabiting intertidal areas near river mouths in Washington, USA, generally exceeding the dietary contribution of intertidal macroalgae and seagrasses.

\section{Offshore and alongshore transport and deposition}

\section{Rocky subtidal habitats}

Barren habitats occur in the rocky subtidal zone and are generated through the grazing action of sea urchins, which denude the substratum of erect fleshy macroalgae. Barrens are characterized by low local productivity (Breen \& Mann 1976, Chapman 1981, Miller 1985), but receive macroalgal subsidies from adjacent kelp beds and forests (Dayton 1985b, Basch \& Tegner 2007, Britton-Simmons et al. 2009, FilbeeDexter \& Scheibling 2012). Basch \& Tegner (2007) found that up to $250-400 \mathrm{~g} \mathrm{~m}^{-2}$ of Macrocystis pyrifera (wet mass) accumulates at depths of 8 to $18 \mathrm{~m}$ off California. Similarly, Britton-Simmons et al. (2009) recorded an average of $514 \mathrm{~g} \mathrm{~m}^{-2}$ of detrital kelp (Laminaria spp., wet mass) at $23 \mathrm{~m}$ depth in Washington. Kelp is the dominant component of macrophyte detritus accumulating in these rocky habitats above $30 \mathrm{~m}$ depth, accounting for $\sim 50 \%$ of detrital biomass in California (Gerard 1976, Harrold \& Reed 1985) and $71 \%$ in Washington (Britton-Simmons et al. 2009).

When detritus is abundant within kelp forests and adjacent areas, sea urchins do not graze attached kelps, but instead form sedentary aggregations or hide within cryptic habitats where they trap detritus as it is transported along-bottom or accumulates
(Mattison et al. 1977, Dean et al. 1984, Harrold \& Reed 1985, Rogers-Bennett et al. 1995, Vanderklift \& Kendrick 2005, Basch \& Tegner 2007, Vanderklift \& Wernberg 2008, Britton-Simmons et al. 2009). When detrital supply becomes limited, sea urchins increase their rate of movement and form grazing fronts that rapidly consume stands of attached kelps (Dayton 1985b, Ebeling et al. 1985, Harrold \& Reed 1985). Low detrital supply, therefore, triggers the transition from a highly productive kelp forest to a low-productivity sea urchin barren.

The onshore advance of grazing fronts of sea urchins is generally limited by wave action, either directly or via the whiplash effect of kelps (Velimirov \& Griffiths 1979, Dayton 1985b, Scheibling et al. 1999, Konar \& Estes 2003, Siddon \& Witman 2003, Lauzon-Guay \& Scheibling 2007). In Nova Scotia, this wave-mediated upper limit of destructive grazing enables kelp beds to persist in shallow bands along the coast (Brady \& Scheibling 2005), while dense populations of sea urchins in adjacent barrens subsist in part on the supply of kelp detritus from the shallows (Kelly et al. 2012). Sea urchins supplied with detrital kelp develop larger gonads than those without access to this food resource (Rogers-Bennett et al. 1995, Basch \& Tegner 2007, Britton-Simmons et al. 2009). Detrital kelp is less abundant along exposed coastlines relative to more sheltered coastlines or bays (Dayton 1985b, Filbee-Dexter \& Scheibling 2012). As a result, sea urchins in barrens on exposed coasts are of lower nutritional condition than those feeding directly on kelps in the shallow subtidal zone, whereas sea urchins in deep depositional areas in protected bays are well nourished (Dayton 1985b, Brady \& Scheibling 2006, K. Filbee-Dexter \& R. E. Scheibling unpubl. data). Detrital subsidy to sea urchins decreases with distance from the kelp bed or forest (Mattison et al. 1977, Rogers-Bennett et al. 1995, Kelly et al. 2012), but is documented for sea urchins on reefs up to $8 \mathrm{~km}$ from the kelp source (Vanderklift \& Wernberg 2008).

Kelp particulates and fecal pellets from sea urchins and other grazers are transported offshore where they are consumed by filter- and deposit-feeding macroinvertebrates, meiofauna and microbes, enhancing secondary production across a range that can extend $>14 \mathrm{~km}$ from the kelp source (Duggins et al. 1989, Kaehler et al. 2006). Along the Atlantic coast of Nova Scotia, sea urchins form dense grazing fronts that advance onshore consuming kelp at a rate of 454 to $530 \mathrm{~g} \mathrm{~d}^{-1}$ (dry mass) across $1 \mathrm{~m}$ of front. This translates to an estimated fecal production rate of 74 to $81 \mathrm{~g} \mathrm{yr}^{-1}$ per linear meter of front, or $20720 \mathrm{~kg}$ 
$\mathrm{d}^{-1}$ across an estimated $280 \mathrm{~km}$ of coastline spanned by these grazing fronts in the mid to late 1990s (Sauchyn \& Scheibling 2009a, Sauchyn et al. 2011). The small ( $2 \mathrm{~mm}$ diameter) fecal pellets are a highly nutritious food source relative to live kelp, and nitrogen, lipid, and available energy content increase rapidly during degradation (Sauchyn \& Scheibling 2009b).

\section{Soft-sediment habitat}

Kelp detritus is transported alongshore or offshore via tidal, bottom, or surface currents to unvegetated soft-sediment habitats ranging from the surf zone to bathyal and abyssal depths. Submarine canyons trap submerged detritus as it is transported by alongshore currents, accumulating massive quantities of material and acting as conduits for detrital transport to the deep sea (Josselyn et al. 1983, Vetter 1995, 1996, Harrold et al. 1998, Vetter \& Dayton 1998, Okey 2003). Macrocystis pyrifera accounted for 12 to $22 \%$ of drift 'parcels' in Carmel Canyon, off California, and $53 \%$ of drift parcels on the adjacent continental shelf (Harrold et al. 1998). Kelp detritus transported over the continental shelf is more likely to be consumed or buried before arrival at the deep sea, compared to that transported via submarine canyons (Vetter \& Dayton 1999). However, the abundance of detrital kelp can decrease by $95 \%$ between 30 and $900 \mathrm{~m}$ depth in submarine canyons off California (Vetter \& Dayton 1999); detrital kelp is sparse $(2.5 \times$ $10^{-2} \mathrm{~g} \mathrm{C} \mathrm{m}^{-2}$ ) at depths of $>1 \mathrm{~km}$ (Smith 1983). Longdistance transport of kelp detritus offshore is more likely to occur via surface dispersal of floating rafts, which ultimately lose buoyancy and sink to the deep sea (Smith 1983, Bernardino et al. 2010). Detrital accumulations (mats) in shallow habitats and submarine canyons are expansive during periods of calm wave action in spring and summer, while wave surge associated with fall and winter storms causes detrital flushing or mat compaction in deeper regions (Vetter 1995, Vetter 1998, Okey 2003).

Kelp detritus is a primary source of food in subtidal soft-sediment habitats, as it is for sandy beaches, attracting diverse assemblages of detritivores, predators, and microbes, whose distribution and secondary production are largely determined by the availability of detritus (Lenanton et al. 1982, Bedford \& Moore 1984, Kim 1992, Vetter 1995, 1996, Okey 1997, Harrold et al. 1998, Vetter \& Dayton 1998, 1999, Hyndes \& Lavery 2005, Bernardino et al. 2010, Krumhansl \& Scheibling 2012). Secondary production rates in de- trital mat communities in submarine canyons exceed those of most other natural systems (Vetter 1995). Juvenile fish use mats of kelp detritus as nursery habitat, feeding on associated amphipods, leptostraceans, and copepods (Lenanton et al. 1982, Vetter 1998, Hyndes \& Lavery 2005). Vetter (1998) experimentally demonstrated that predation rate on these crustaceans decreases with mat thickness, indicating that detrital mats also provide structural protection. During calm conditions, thick bacterial mats colonize the surface of detrital deposits, causing crustaceans to move into open patches where they are more susceptible to predators (Vetter 1998). Bacterial mats are unable to form during periods of frequent wave disturbance (Vetter 1998).

Community dynamics within mats of detrital kelp and underlying sediments are largely dependent on the size and residence time of deposits, which in turn are determined by physical processes and the rate of consumption by large herbivores, such as sea urchins (Scheibling \& Raymond 1990, Kim 1992, Okey 1997, 2003, Norkko et al. 2000). In small deposits with short residence times, or in ephemeral deposits in wave- or current-swept locations, faunal abundance and diversity are locally enhanced relative to the surrounding sediments (Lenanton et al. 1982, Vetter 1995, 1996, Harrold et al. 1998, Vetter \& Dayton 1998, 1999, Hyndes \& Lavery 2005). In larger and more persistent deposits, hypoxic conditions can develop in the bottom layers of detrital mats. In some cases this leads to widespread anoxia and decreased microbial and faunal abundances within the deposit and underlying sediments (Scheibling \& Raymond 1990, Tzetlin et al. 1997, Mokievsky et al. 2005). Local hypoxia also can occur in sediments beneath small deposits with relatively short residence times (Thrush 1986, Vetter 1996, Vetter \& Dayton 1998, Okey 2003, Bernardino et al. 2010). Opportunistic species that tolerate low oxygen and high sulfide conditions, such as capitellid and dorvellid worms, can occur in high abundance beneath deposits (Levin \& Smith 1984, Thrush 1986, Vetter 1996, Okey 2003, Bernardino et al. 2010). More diverse faunal assemblages may accumulate in the vicinity of detritus, where the adverse effects of organic enrichment are less severe (Thrush 1986). In large, persistent deposits, a greater diversity of fauna can occur on the surface and edges of mats, where detrital material is freshly deposited and turns over more rapidly than material in lower layers (Tzetlin et al. 1997).

Kelp detritus also is deposited in intertidal surfgrass and subtidal seagrass beds, where it subsidizes multiple trophic levels (Hori 2006, Wernberg et al. 
2006). Wernberg et al. (2006) documented large deposits of detrital kelp within seagrass beds hundreds of meters from a kelp source in southwestern Australia. Seagrasses and seagrass epiphytes assimilate kelp-derived nitrogen that is leached during detrital breakdown (Hyndes et al. 2012). Kelp deposits also attract assemblages of herbivores, which in some locations consume most of the detritus within days (Wernberg et al. 2006). When given a choice, herbivores and detritivores that inhabit temperate seagrass beds preferentially consume kelp and other macroalgae over seagrasses (Smit et al. 2006, Doropoulos et al. 2009). Stable isotope analysis shows that seagrass is a less important dietary source than imported and autochthonous macroalgae, periphyton, and epiphytic algae in seagrass food webs (Stephenson et al. 1986, Smit et al. 2006, Hyndes et al. 2012). Doropoulos et al. (2009) suggest that the importance of macroalgal subsidies to seagrass consumers varies seasonally in response to changing levels of production by autochthonous macroalgae and periphyton.

\section{Long distance sea-surface transport}

Kelps and other macroalgal species with pneumatocysts are buoyant after dislodgement from the substrate, and can accumulate in rafts that drift with surface currents and winds (Helmuth et al. 1994, Hobday 2000a, Hinojosa et al. 2010). The estimated wet biomass of floating rafts of giant kelp Macrocystis pyrifera in California and Chile can range from 100 to $1500 \mathrm{~kg} \mathrm{~km}^{-2}$ (Hobday 2000a, Hinojosa et al. 2010). In South Africa, rafts of M. pyrifera can be up to $6 \mathrm{~m}$ in diameter and $1 \mathrm{~m}$ deep, and contain as many as 200 individual thalli (Helmuth et al. 1994). Dispersal of rafts is low when prevailing winds are onshore (Harrold \& Lisin 1989) or in areas with large freshwater input such as fjords (Hinojosa et al. 2010). Kelp rafts may disperse hundreds of kilometers in areas with strong unidirectional currents (Helmuth et al. 1994, Fraser et al. 2010). The dispersal and spatial distribution of kelp rafts vary seasonally in response to changing wind and current patterns (Harrold \& Lisin 1989, Hobday 2000a, Hinojosa et al. 2010).

The dispersal of a kelp raft is also dependent on environmental and biological factors that affect buoyancy (Rothausler et al. 2009). Rothausler et al. $(2009,2011 \mathrm{a}, \mathrm{b})$ tested the interactive effects of temperature, UV, and grazing by amphipods on the photosynthesis, growth, and reproduction of floating Macrocystis pyrifera. Macrocystis pyrifera is able to withstand a wide range of UV conditions by adjust- ing photosynthetic pigments and photochemical reactions (Rothausler et al. 2011a,b), but photosynthesis, growth, and reproduction are greatly reduced in water temperatures above $20^{\circ} \mathrm{C}$, which causes degradation and loss of buoyancy (Rothausler et al. 2009, 2011a). The effect of grazing amphipods on biomass and buoyancy is highest at moderate water temperatures $\left(15\right.$ to $\left.20^{\circ} \mathrm{C}\right)$ where grazing rate exceeds kelp growth (Rothausler et al. 2009). At low temperatures $\left(<15^{\circ} \mathrm{C}\right)$, kelp growth can compensate for biomass lost to grazers (Rothausler et al. 2009). These results indicate that raft dispersal is greatest in waters below $15^{\circ} \mathrm{C}$. Low seawater nitrate levels may also reduce buoyancy (Hobday 2000a).

Kelp rafts accumulate diverse communities of invertebrates while drifting (Edgar 1987, Hobday 2000 b, Thiel \& Gutow 2005). Some organisms remain attached to kelps following dislodgement from the substrate, while others settle or become attached to rafts they encounter during drifting. It is hypothesized that rafting is an important mechanism of longdistance dispersal for invertebrates (Highsmith 1985, Edgar 1987, Helmuth et al. 1994, Fraser et al. 2010), particularly for species that have a short larval phase or brood their young to a benthic stage (Highsmith 1985, Helmuth et al. 1994). Evidence for this includes genetic linkages between broadly distributed populations of brooding species (Fraser et al. 2009), and the discovery of individuals brooding young on kelp rafts (Helmuth et al. 1994). Holmquist (1994) proposed that dispersal via rafting is more effective than larval dispersal because of a lower risk of mortality. Kelps remain reproductive while drifting (Rothausler et al. 2009), and propagules of other algal and plant species have been collected from kelp rafts (Edgar 1987), indicating that dispersal via kelp rafts is not limited to invertebrates.

\section{HUMAN IMPACTS ON KELP BIOMASS AND DETRITAL SUBSIDY}

Anthropogenic pressures on natural systems have mounted over the past centuries, resulting in profound changes in the marine environment (Worm et al. 2005, Lotze et al. 2006, Jackson 2008). Kelp ecosystems are no exception to this trend, and may be particularly sensitive given their proximity to human populations. A suite of anthropogenic factors causes declines in kelp biomass and population size, which reduces rates of detrital production (Krumhansl \& Scheibling 2011a). Fishing high-level predators releases sea urchin populations and leads to the 
destructive grazing of kelp beds and forests (Steneck et al. 2002). Climate change is expected to cause large-scale losses in kelp biomass and decrease the resilience of kelp beds and forests due to warming sea surface temperatures, changes in the nutrient dynamics of the water column, and increases in storm frequency and intensity (Steneck et al. 2002, Martinez et al. 2003, Springer et al. 2010, Wernberg et al. 2010). Large-scale kelp canopy loss is linked to warm water temperatures associated with the disruption of upwelling cycles during El Niño years (Gunnill 1985, Steneck et al. 2002, Martinez et al. 2003, Vasquez et al. 2006, Foster \& Schiel 2010, Springer et al. 2010). Storms that cause large wave events and reduce kelp biomass (Gerard 1976, Luning 1979, Gunnill 1985, Seymour et al. 1989, Reed et al. 2008) are likely to have greater long-term effects as the incidence of severe storm events increases (Easterling et al. 2000, Byrnes et al. 2011). Declines in kelp biomass also have occurred in response to coastal pollution (Steneck et al. 2002, Connell et al. 2008, Foster \& Schiel 2010) and development and extraction activities that disrupt subtidal habitat (Pulfrich et al. 2003) and cause run-off of toxic materials, warm water, and sediments (Medina et al. 2005, Springer et al. 2010). The introduction and spread of non-native algal species can replace kelps, altering the species composition and nutritional quality of detritus (Bishop et al. 2010, Krumhansl \& Scheibling 2012).

Direct removal of the kelp canopy through harvesting also can have severe repercussions for kelp biomass and detrital production. Kelp is primarily used for human consumption (Rothman et al. 2006, Peteiro \& Freire 2011), alginic acid extraction (Vasquez 2008, Vea \& Ask 2011), and as feed for cultured abalone (Troell et al. 2006, Macchiavello et al. 2010). Canopy harvesting has increased dramatically in recent decades (Rothman et al. 2006, Vasquez 2008, Thompson et al. 2010, Vea \& Ask 2011). Kelp is currently harvested in many countries worldwide (including the USA, Canada, Mexico, South Africa, Chile, Australia, New Zealand, Japan, China, Taiwan, Ireland, Norway, the UK, and Iceland) and markets continue to expand (Adams et al. 2009, 2011). Historically, kelp harvesting involved collection of beach-cast material; however, since the 1960s this has been replaced by direct harvesting in response to increasing demand (Vasquez 2008, Vea \& Ask 2011). With growing concern that wild populations of kelp cannot sustain harvesting at the current rate, the harvest potential of currently unexploited areas, such as the Arctic, is being investigated (Sharp et al. 2008) and suspended culture of kelps has been developed in some bays and offshore areas (Troell et al. 2006, Macchiavello et al. 2010, Peteiro \& Freire 2011, Radiarta et al. 2011). Kelp mariculture may relieve some of the pressure on natural populations, but little is known about its ecological impact. Cultured kelp is a source of detritus (Yoshikawa et al. 2001), but at high density, suspended kelps can reduce current speeds (Shi et al. 2011) and may cause organic enrichment of local sediments and anoxia.

The negative effects of kelp biomass loss may extend well beyond the local kelp community to areas subsidized by kelp detritus. We have demonstrated that kelp detritus is transported to a wide range of habitats that extend from tens of meters to hundreds of kilometers from the source of production. Patterns of secondary production and community organization in these communities are tightly linked to detrital resources, indicating that kelp productivity fuels regional-scale productivity. A loss of detrital resources can therefore be predicted to have broad-scale ecological consequences. This has been demonstrated in beach systems, where a reduction kelp detrital input due to a decline in subtidal kelp cover or the removal of beach-cast material causes declines in the richness, abundance, and biomass of macrofauna and shorebirds (Bradley \& Bradley 1993, Kirkman \& Kendrick 1997, Dugan et al. 2003). Similar effects of subtidal kelp removal can be expected in other habitats subsidized by kelp detritus.

\section{CONCLUSIONS AND RECOMMENDATIONS FOR FUTURE RESEARCH}

Although most of the primary production of kelp beds and forests flows through detrital pathways, detrital production is quantified for relatively few kelp populations. These measurements are sparsely distributed throughout the temperate range of kelps and are highly variable within and among kelp species, underscoring the need for more location- and species-specific measurements. There is only 1 estimate for an Arctic kelp population, and detrital production rates are missing entirely for many kelp genera (e.g. Nereocystis, Agarum, Alaria, Costaria, and Pterogophora). Variation in detrital production rates and the relative importance of erosion versus dislodgement as production processes may be related to characteristics of particular kelp species or populations (e.g. morphotype, density), or to the physical environment (e.g. wave exposure, temperature regime, latitude). Understanding the mechanisms that 
regulate detrital production at large spatial scales would provide insight into the potential response of communities to environmental change, which may be greatest at the lower and higher latitudinal limits of kelps. A more complete quantification of detrital production throughout the geographic range of kelps and simultaneous measures of erosion and dislodgement are required to address these hypotheses and to improve our ability to model energy flow through coastal systems.

The extent of detrital subsidy by kelps is determined by the magnitude and direction of detrital export. The proportion of detrital production exported or retained is well quantified for seagrass (Heck et al. 2008), salt marsh (Gallagher et al. 1980, Dame \& Stilwell 1984, Bouchard \& Lefeuvre 2000), and mangrove communities (Kristensen et al. 2008), likely because these macrophyte assemblages typically occur in semi-enclosed bays or estuaries where exported material can be readily trapped and measured. Kelp communities, on the other hand, generally occur on semi-protected or exposed coasts where trapping and quantifying material flows is considerably more difficult. Less detritus may be retained in kelp beds and forests relative to seagrass meadows, salt marshes, and mangrove forests because kelps grow only on rocky substrata in areas with moderate to high wave exposure, where trapping and burial are unlikely. Export rates in kelp ecosystems can be estimated as the difference between simultaneous measures of detrital production and accumulation within kelp beds or forests. Residence time of kelp fragments or thalli manually deposited within these habitats can provide insight into environmental factors that govern detrital export rates and seasonal variation. The relative importance of inshore versus offshore transport can be estimated by relating detrital production rates to arrival rates in habitats along an onshore-offshore gradient. Transport direction and distance also can be measured by tracking labeled detrital fragments and thalli (e.g. with flagging tape) using diver surveys, towed video, or ROVs.

Kelps are a dominant component of detrital accumulations in a variety of intertidal and subtidal habitats, although few studies quantify the composition of these deposits and the proportional contribution of kelps. The relative contribution of kelps and other macrophytes to the detrital pool will depend on their abundance in coastal habitats, physical characteristics of detritus that affect transport, and physical transport mechanisms that can vary across habitat types. A comprehensive understanding of energy flow in coastal systems requires consideration of all local sources of macrophyte detritus. The composition of detrital deposits affects their turnover rate and patterns of colonization by microbes and meio- and macrofauna on the surface of detritus and in underlying sediments. Future research should emphasize comparisons of subtidal abundance and distribution, detrital production rates, transport, and depositional dynamics between kelps and other dominant macrophytes. Examining the species composition of macrophytes in detrital deposits across broad scales within regions could indicate the relative importance of different detrital sources to macrofaunal communities in various habitat types. The link between spatial patterns of production and deposition of different macrophyte species may be clearer when these species occupy different physical environments.

Kelp detritus subsidizes consumers across a wide range of marine and terrestrial habitats, acting as a major form of connectivity in coastal systems, which enhances species abundance, diversity, productivity, and reproductive output. Most studies focus primarily on kelp subsidies to consumers. The potential for kelp to subsidize primary producers was only recently demonstrated (Hyndes et al. 2012). Kelps rapidly leach nutrients during microbial breakdown (Koop et al. 1982), contributing to the nutrient pool available to nearby primary producers. This nutrient input may be particularly important in oligotrophic systems, and where kelp is degrading in the direct vicinity of other primary producers, such as seagrasses and dune grasses.

Most studies examining the consequences of detrital subsidies in receiving communities have been conducted over relatively short time scales. Seasonal dynamics in some detritus-based communities (e.g. in submarine canyons or on sandy beaches) are related to variation in physical factors that determine the size and residence time of detrital deposits. In many habitats the deposition of kelp detritus is a sporadic occurrence. Receiving communities may be adapted to protracted periods of low food abundance punctuated by detrital food pulses that occur over short time scales (Sears et al. 2004, Filbee-Dexter \& Scheibling 2012). These pulsed depositional events may play an important role in maintaining gamma diversity, especially in the deep sea (Bernardino et al. 2010). Long-term environmental changes and reductions in kelp populations may have different and more pronounced consequences for detritus-based communities than changes resulting from short-term environmental variability.

Many of the species that consume detritus within kelp beds and forests and in adjacent systems (e.g. 
sea urchins, abalone, sea cucumbers, and mussels) are the basis of valuable coastal fisheries. These species also are prey for higher trophic level consumers (e.g. lobsters, ground fish, and sea otters) that have commercial or ecological importance (Dayton et al. 1998, Steneck et al. 2002). Consequently, the provisioning of detrital food webs is a major ecosystem service provided by kelp beds and forests. Loss of kelp biomass threatens this important function through reduction or elimination of detrital production. Kelp populations require more than 6 yr to recover from canopy harvesting (Lorentsen et al. 2010), and declines in the order of decades are documented following overfishing of apex predators and trophic cascades, repeated El Niño events, or freshwater and sewage run-off (Mann 1977, Dayton et al. 1998, Steneck et al. 2002, Foster \& Schiel 2010). Dire ecological and economic consequences can be expected as a result of long-term declines in kelp canopy. Effective management of coastal ecosystems and resources demands a broader consideration of the role of detrital flows from kelp and other marine macrophytes in determining overall productivity on regional scales.

Acknowledgements. We thank J. Witman, T. Romanuk, H. Lotze, J. Grant, M. Wong and an anonymous reviewer for comments on an earlier draft of the manuscript. This research was funded by a Discovery Grant and a Strategic Networks Grant (Canadian Healthy Oceans Network) to R.E.S. K.A.K. was supported by a Dalhousie Scholarship.

\section{LITERATURE CITED}

- Adams JM, Gallagher JA, Donnison IS (2009) Fermentation study on Saccharina latissima for bioethanol production considering variable pre-treatments. J Appl Phycol 21: 569-574

Adams JMM, Toop TA, Donnison IS, Gallagher JA (2011) Seasonal variation in Laminaria digitata and its impact on biochemical conversion routes to biofuels. Bioresour Technol 102:9976-9984

Alkemade R, van Rijswijk P (1993) Path analysis of the influence of substrate composition on nematode numbers and on decomposition of stranded seaweed at an Antarctic coast. Neth J Sea Res 31:63-70

> Anderson WB, Polis GA (1998) Marine subsidies of island communities in the Gulf of California: evidence from stable carbon and nitrogen isotopes. Oikos 81:75-80

> Barrett K, Anderson WB, Wait A, Grismer LL, Polis GA, Rose MD (2005) Marine subsidies alter the diet and abundance of insular and coastal lizard populations. Oikos 109:145-153

Basch LV, Tegner MJ (2007) Reproductive responses of purple sea urchin (Strongylocentrotus purpuratus) populations to environmental conditions across a coastal depth gradient. Bull Mar Sci 81:255-282

> Bedford AP, Moore PG (1984) Macrofaunal involvement in the sublittoral decay of kelp debris: the detritivore com- munity and species interactions. Estuar Coast Shelf Sci 18:97-111

- Bernardino AF, Smith CR, Baco A, Altamira I, Sumida PYG (2010) Macrofaunal succession in sediments around kelp and wood falls in the deep NE Pacific and community overlap with other reducing habitats. Deep-Sea Res I 57:708-723

Biedka RF, Gosline JM, DeWreed RE (1987) Biomechanical analysis of wave-induced mortality in the marine alga Pterygophora californica. Mar Ecol Prog Ser 36:163-170

Bishop MJ, Coleman MA, Kelaher BP (2010) Cross-habitat impacts of species decline: response of estuarine sediment communities to changing detrital resources. Oecologia 163:517-525

> Black R (1976) The effects of grazing by the limpet, Acmaea insessa, on the kelp Egregia laevigata, in the intertidal zone. Ecology 57:265-277

Bouchard V, Lefeuvre JC (2000) Primary production and macro-detritus dynamics in a European salt marsh: carbon and nitrogen budgets. Aquat Bot 67:23-42

Bradley RA, Bradley DW (1993) Wintering shorebirds increase after kelp (Macrocystis) recovery. Condor 95: 372-376

> Brady SM, Scheibling RE (2005) Repopulation of the shallow subtidal zone by green sea urchins (Strongylocentrotus droebachiensis) following mass mortality in Nova Scotia, Canada. J Mar Biol Assoc UK 85:1511-1517

> Brady SM, Scheibling RE (2006) Changes in growth and reproduction of green sea urchins, Strongylocentrotus droebachiensis (Muller), during repopulation of the shallow subtidal zone after mass mortality. J Exp Mar Biol Ecol 335:277-291

Brady-Campbell MM, Campbell DB, Harlin MM (1984) Productivity of kelp (Laminaria spp.) near the southern limit in the Northwestern Atlantic Ocean. Mar Ecol Prog Ser 18:79-88

> Breen PA, Mann KA (1976) Destructive grazing of kelp by sea urchins in eastern Canada. J Fish Res Board Can 33:1278-1283

Britton-Simmons KH, Foley G, Okamoto D (2009) Spatial subsidy in the subtidal zone: utilization of drift algae by a deep subtidal sea urchin. Aquat Biol 5:233-243

Britton-Simmons KH, Rhoades AL, Pacunski RE, Galloway AWE and others (2012) Habitat and bathymetry influence the landscape-scale distribution and abundance of drift macrophytes and associated invertebrates. Limnol Oceanogr 57:176-184

Brown AC (1964) Food relations on the intertidal sandy beaches of the Cape Peninsula. S Afr J Sci 60:35-41

Brown MT, Nyman MA, Keogh JA, Chin NKM (1997) Seasonal growth of the giant kelp Macrocystis pyrifera in New Zealand. Mar Biol 129:417-424

> Buchsbaum R, Valiela I, Swain T, Dzierzeski M, Allen S (1991) Available and refractory nitrogen in detritus of coastal vascular plants and macroalgae. Mar Ecol Prog Ser 72:131-143

> Burke DJ, Hamerlynck EP, Hahn D (2002) Effect of arbuscular mycorrhizae on soil microbial populations and associated plant performance of the salt marsh grass Spartina patens. Plant Soil 239:141-154

> Bustamante RH, Branch GM (1996) The dependence of intertidal consumers on kelp-derived organic matter on the west coast of South Africa. J Exp Mar Biol Ecol 196: 1-28

> Bustamante RH, Branch GM, Eekhout S (1995) Maintenance of an exceptional intertidal grazer biomass in South Africa: subsidy by subtidal kelps. Ecology 76:2314-2329 
Byrnes JE, Reed DC, Cardinale BJ, Cavanaugh KC, Holbrook SJ, Schmitt RJ (2011) Climate-driven increases in storm frequency simplify kelp forest food webs. Glob Change Biol 17:2513-2524

> Camilleri J (1989) Leaf choice by crustaceans in a mangrove forest in Queensland. Mar Biol 102:453-459

> Campbell JE, Fourqurean JW (2009) Interspecific variation in the elemental and stable isotope content of seagrasses in South Florida. Mar Ecol Prog Ser 387:109-123

> Canepuccia AD, Alberti J, Pascual J, Alvarez G, Cebrian J, Iribarne OO (2010) ENSO episodes modify plant/terrestrial-herbivore interactions in a southwestern Atlantic salt marsh. J Exp Mar Biol Ecol 396:42-47

Cavanaugh KC, Siegel DA, Reed DC, Dennison PE (2011) Environmental controls of giant-kelp biomass in the Santa Barbara Channel, California. Mar Ecol Prog Ser 429:1-17

$>$ Cebrian J (1999) Patterns in the fate of production in plant communities. Am Nat 154:449-468

> Cebrian J, Lartigue J (2004) Patterns of herbivory and decomposition in aquatic and terrestrial systems. Ecol Monogr 74:237-259

> Cerda O, Karsten U, Rothausler E, Tala F, Thiel M (2009) Compensatory growth of the kelp Macrocystis integrifolia (Phaeophyceae, Laminariales) against grazing of Peramphithoe femorata (Amphipoda, Amphithoidae) in northern-central Chile. J Exp Mar Biol Ecol 377:61-67

> Chapman ARO (1981) Stability of sea urchin dominated barren grounds following destructive grazing of kelp in St. Margaret's Bay, Eastern Canada. Mar Biol 62: 307-311

> Chapman ARO (1984) Reproduction, recruitment and mortality in two species of Laminaria in southwest Nova Scotia. J Exp Mar Biol Ecol 78:99-109

> Chapman ARO, Lindley JE (1980) Seasonal growth of Laminaria solidungula in the Canadian high arctic in relation to irradiance and dissolved nutrient concentrations. Mar Biol 57:1-5

Chen J, Wang L, Yanli L, Zhang W, Fu X, Le Y (2012) Effect of Spartina alterniflora invasion and its controlling technologies on soil microbial respiration of a tidal wetland in Chongming Dongtan, China. Ecol Eng 41:52-59

Colombini I, Chelazzi L (2003) Influence of marine allochthonous input on sandy beach communities. Oceanogr Mar Biol Annu Rev 41:115-159

> Connell SD, Russell BD, Turner DJ, Shepherd SA and others (2008) Recovering a lost baseline: missing kelp forests from a metropolitan coast. Mar Ecol Prog Ser 360:63-72

Cranford PJ, Grant J (1990) Particle clearance and absorption of phytoplankton and detritus by the sea scallop Placopecten magellanicus (Gmelin). J Exp Mar Biol Ecol 137:105-121

$>$ Dai J, Sun MY, Culp RA, Noakes JE (2005) Changes in chemical and isotopic signatures of plant materials during degradation: implication for assessing various organic inputs to estuarine systems. Geophys Res Lett 32: L13608

> Dame RF, Stilwell D (1984) Environmental factors influencing macrodetritus flux in a North Inlet estuary. Estuar Coast Shelf Sci 18:721-726

$>$ Dayton PK (1985a) Ecology of kelp communities. Annu Rev Ecol Syst 16:215-245

> Dayton PK (1985b) The structure and regulation of some South American kelp communities. Ecol Monogr 55: 447-468
Dayton PK, Tegner MJ, Parnell PE, Edwards PB (1992) Temporal and spatial patterns of disturbance and recovery in a kelp forest community. Ecol Monogr 62:421-445

> Dayton PK, Tegner MJ, Edwards PB, Riser KL (1998) Sliding baselines, ghosts, and reduced expectations in kelp forest communities. Ecol Appl 8:309-322

> Dean PR, Hurd CL (2007) Seasonal growth, erosion rates, and nitrogen and photosynthetic ecophysiology of Undaria pinnatifida (Heterokontophyta) in southern New Zealand. J Phycol 43:1138-1148

Dean TA, Schroeter SC, Dixon J (1984) Effects of grazing by two species of sea urchins (Strongylocentrotus fransicanus and Lytechinus anamesus) on recruitment and survival of two species of kelp (Macrocystis pyrifera and Pterygophora californica). Mar Biol 78:301-313

Denny MW (2006) Ocean waves, nearshore ecology, and natural selection. Aquat Ecol 40:439-461

> Denny M, Gaylord BP, Cowen EA (1997) Flow and flexibility: II. The roles of size and shape in determining wave forces on the bull kelp Nereocystis luetkeana. J Exp Biol 200:3165-3183

> Doropoulos C, Hyndes GA, Lavery PS, Tuya F (2009) Dietary preferences of two seagrass inhabiting gastropods: allochthonous vs. autochthonous resources. Estuar Coast Shelf Sci 83:13-18

Druehl LD, Wheeler WN (1986) Population biology of Macrocystis integrifolia from British Columbia, Canada. Mar Biol 90:173-179

Dugan JE, Hubbard DM, McCrary MD, Pierson MO (2003) The response of macrofauna communities and shorebirds to macrophyte wrack subsidies on exposed sandy beaches of southern California. Estuar Coast Shelf Sci 58, Suppl:25-40

> Dugan JE, Hubbard DM, Page HM, Schimel JP (2011) Marine macrophyte wrack inputs and dissolved nutrients in beach sands. Estuaries Coasts 34:839-850

> Duggins DO, Eckman JE (1997) Is kelp detritus a good food for suspension feeders? Mar Biol 128:489-495

Duggins DO, Simenstad CA, Estes JA (1989) Magnification of secondary production by kelp detritus in coastal marine ecosystems. Science 245:170-173

> Duggins D, Eckman JE, Siddon CE, Klinger T (2001) Interactive roles of mesograzers and current flow in survival of kelps. Mar Ecol Prog Ser 223:143-155

> Duggins DO, Eckman JE, Siddon CE, Klinger T (2003) Population, morphometric and biomechanical studies of three understory kelps along a hydrodynamic gradient. Mar Ecol Prog Ser 265:57-76

Dunton KH (1984) An annual carbon budget for an arctic kelp community. In: Barnes PW, Schell DM, Reimnitz E (eds) The Alaskan Beaufort Sea: ecosystems and environments. Academic Press, Orlando, FL, p 311-326

> Dunton KH, Schell DM (1987) Dependence of consumers on macroalgal (Laminaria solidungula) carbon in an arctic kelp community: $\delta^{13} \mathrm{C}$ evidence. Mar Biol 93: 615-625

Easterling DR, Meehl GA, Parmesan C, Changnon SA, Karl TR, Mearns LO (2000) Climate extremes: observations, modeling, and impacts. Science 289:2068-2074

> Ebeling AW, Laur DR, Rowley RJ (1985) Severe storm disturbances and reversal of community structure in a southern California kelp forest. Mar Biol 84:287-294

Edgar GJ (1987) Dispersal of faunal and floral propagules associated with drifting Macrocystis pyrifera plants. Mar Biol 95:599-610 
Fauchald K, Jumars PA (1979) The diet of worms: a study of polychaete feeding guilds. Oceanogr Mar Biol Annu Rev 17:193-284

Feller IC, Whigham DF, O'Neill JP, McKee KL (1999) Effects of nutrient enrichment on within-stand cycling in a mangrove forest. Ecology 80:2193-2205

Filbee-Dexter K, Schiebling RE (2012) Hurricane-mediated defoliation of kelp beds and pulsed delivery of kelp detritus to offshore sedimentary habitats. Mar Ecol Prog Ser 455:51-64

Foster MS, Schiel DR (2010) Loss of predators and the collapse of southern California kelp forests (?): alternatives, explanations and generalizations. J Exp Mar Biol Ecol 393:59-70

Fourqurean JW, Zieman JC (2002) Nutrient content of the seagrass Thalassia testudinum reveals regional patterns of relative availability of nitrogen and phosphorus in the Florida Keys USA. Biochemistry 61:229-245

Fourqurean JW, Moore TO, Fry B, Hollibaugh JT (1997) Spatial and temporal variation in C:N:P ratios, $\partial^{15} \mathrm{~N}$, and $\partial^{13} \mathrm{C}$ of eelgrass Zostera marina as indicators of ecosystem processes, Tomales Bay, California, USA. Mar Ecol Prog Ser 157:147-157

Fraser CI, Nikula R, Spencer HG, Waters JM (2009) Kelp genes reveal effects of subantarctic sea ice during the last glacial maximum. P Natl Acad Sci USA 106: 3249-3253

> Fraser CI, Nikula R, Waters JM (2011) Oceanic rafting by a coastal community. Proc Biol Sci 278:649-655

Gagné J, Mann K, Chapman ARO (1982) Seasonal patterns of growth and storage in Laminaria longicruris in relation to differing patterns of availability in nitrogen in the water. Mar Biol 69:91-101

Gallagher JL, Reimold RJ, Linthurst RA, Pfeiffer WJ (1980) Aerial production, mortality, and mineral accumulationexport dynamics in Spartina alterniflora and Juncus roemerianus plant stands in a Georgia salt marsh. Ecology 61:303-312

Gerard VA (1976) Some aspects of material dynamics and energy flow in a kelp forest in Monterey Bay, California. PhD dissertation, University of California, Santa Cruz

Gerard VA, Mann KH (1979) Growth and production of Laminaria longicruris (Phaeophyta) populations exposed to different intensities of water movement. J Phycol 15: 33-41

> Giddins RL, Lucas JS, Neilson MJ, Richards GN (1986) Feeding ecology of the mangrove crab Neosarmatium smithi (Crustacea: Decapoda: Sesarmidae). Mar Ecol Prog Ser 33:147-155

Gravel D, Moquet N, Loreau M, Guichard F (2010) Patch dynamics, persistence, and species coexistence in metaecosystems. Am Nat 176:289-302

$>$ Griffiths CL, Stenton-Dozey J (1981) The fauna and rate of degradation of stranded kelp. Estuar Coast Shelf Sci 12: 645-653

Griffiths CL, Stenton-Dozey J, Koop K (1983) Kelp wrack and the flow of energy through a sandy beach ecosystem. In: McLachlan A, Erasmus T (eds) Sandy beaches as ecosystems. W. Junk Publishers, The Hague, p 547-556

> Gunnill FC (1985) Population fluctuations of seven macroalgae in southern California during 1981-1983 including effects of severe storms and an El Niño. J Exp Mar Biol Ecol 85:149-164

Haines EB (1977) The origin of detritus in Georgia salt marsh estuaries. Oikos 29:254-260
Hansen JA (1984) Accumulation of macrophyte wrack along sandy beaches in Western Australia: biomass, decomposition rate, and significance in supporting nearshore production. PhD dissertation, University of Western Australia, Perth

Harrold C, Lisin S (1989) Radio-tracking rafts of giant kelp: local production and regional transport. J Exp Mar Biol Ecol 130:237-251

Harrold C, Reed DC (1985) Food availability, sea urchin grazing, and kelp forest community structure. Ecology 66:1160-1169

> Harrold C, Light K, Lisin S (1998) Organic enrichment of submarine-canyon and continental shelf benthic communities by macroalgal drift imported from nearshore kelp forests. Limnol Oceanogr 43:669-678

Hatcher BG, Chapman ARO, Mann KH (1977) An annual carbon budget for the kelp Laminaria longicruris. Mar Biol 44:85-96

Hatcher BG, Kirkman H, Wood WF (1987) Growth of the kelp Ecklonia radiata near the northern limit of its range in Western Australia. Mar Biol 95:63-73

Hayashida F (1977) On age and growth of brown alga, Ecklonia cava Kjellman, forming aquatic forest. Bull Jpn Soc Sci Fish 43:1043-1051

Hayes WB (1974) Sand-beach energetics: importance of the isopod Tylos punctatus. Ecology 55:838-847

Heck KL, Carruthers TJB, Duarte CM, Hughes AR, Kendrick G, Orth RJ, Williams SW (2008) Trophic transfers from seagrass meadows subsidize diverse marine and terrestrial consumers. Ecosystems 11:1198-1210

Helmuth B, Veit RR, Holberton R (1994) Long-distance dispersal of a subantarctic brooding bivalve (Gaimardia trapensina) by kelp-rafting. Mar Biol 120:421-426

Henley WH, Dunton KH (1995) A seasonal comparison of carbon, nitrogen, and pigment content in Laminaria solidungula and L. saccharina (Phaeophyta) in the Alaskan Arctic. J Phycol 31:325-331

> Hepburn CD, Holborow JD, Wing SR, Frew RD, Hurd CL (2007) Exposure to waves enhances the growth rate and nitrogen status of the giant kelp Macrocystis pyrifera. Mar Ecol Prog Ser 339:99-108

Highsmith RC (1985) Floating and algal rafting as potential dispersal mechanisms in brooding invertebrates. Mar Ecol Prog Ser 25:169-179

> Hinojosa IA, Pizarro M, Ramos M, Thiel M (2010) Spatial and temporal distribution of floating kelp in the channels and fjords of southern Chile. Estuar Coast Shelf Sci 87:367-377

Hladyz S, Gessner MO, Giller PS, Pozo J, Woodward G (2009) Resource quality and stoichiometric constraints on stream ecosystem functioning. Freshw Biol 54: 957-970

Hobday AJ (2000a) Abundance and dispersal of drifting kelp Macrocystis pyrifera in the Southern California Bight. Mar Ecol Prog Ser 195:101-116

Hobday AJ (2000b) Persistence and transport of fauna on drifting kelp (Macrocystis pyrifera (L.) C. Agardh) rafts in the Southern California Bight. J Exp Mar Biol Ecol 253:75-96

> Holmquist JG (1994) Benthic macroalgae as a dispersal mechanism for fauna: influence of a marine tumbleweed. J Exp Mar Biol Ecol 180:235-251

$>$ Hori M (2006) Intertidal surfgrass as an allochthonous resource trap from the subtidal habitat. Mar Ecol Prog Ser 314:89-96 
Hurd CL, Durante KM, Chia FS, Harrison PJ (1994) Effect of bryozoan colonization on inorganic $\mathrm{N}$ acquisition by the kelps Agarum fimbriatum and Macrocystis integrifolia. Mar Biol 121:167-173

Huxel GR, McCann K (1998) Food web stability: the influence of trophic flows across habitats. Am Nat 152: 460-469

> Huxel GR, McCann K, Polis GA (2002) Effects of partitioning allochthonous and autochthonous resources on food web stability. Ecol Res 17:419-432

Huxel GR, Polis GA, Holt RD (2004) At the frontier of the integration of food web ecology and landscape ecology. In: Polis GA, Power ME, Huxel GA (eds) Food webs at the landscape level. University of Chicago Press, Chicago, IL, p 424-451

> Hyndes GA, Lavery PS (2005) Does transported seagrass provide an important trophic link in unvegetated, nearshore areas? Estuar Coast Shelf Sci 63:633-643

> Hyndes GA, Lavery PS, Doropoulos C (2012) Dual processes for cross-boundary subsidies: incorporation of nutrients from reef-derived kelp into a seagrass ecosystem. Mar Ecol Prog Ser 445:97-107

> Iken K, Amsler CD, Amsler MO, McClintock JB, Baker BJ (2009) Field studies on deterrent properties of phlorotannins in Antarctic brown algae. Bot Mar 52:547-557

> Inglis G (1989) The colonization and degradation of stranded Macrocystis pyrifera (L.) C. Ag. by the macrofauna of a New Zealand sandy beach. J Exp Mar Biol Ecol 125:203-217

Jackson JBC (2008) Ecological extinction and evolution in a brave new ocean. Proc Natl Acad Sci USA 105: 11458-11465

> Jimenez JM, Wieski K, Marczak LB, Ho CK, Pennings SC (2012) Effects of an omnivorous katydid, salinity, and nutrients on a planthopper-Spartina food web. Estuar Coast 35:475-485

> Johnson CR, Mann KH (1986) The importance of plant defense abilities to the structure of subtidal seaweed communities: The kelp Laminaria longicruris de la Pylaie survives grazing by the snail Lacuna vincta (Montagu) at high population densities. J Exp Mar Biol Ecol 97: 231-267

Johnson MW, Heck KL, Fourqurean JW (2006) Nutrient content of seagrasses and epiphytes in the northern Gulf of Mexico: evidence of phosphorus and nitrogen limitation. Aquat Bot 85:103-111

Johnston CS, Jones RG, Hunt RD (1977) A seasonal carbon budget for a laminarian population in a Scottish sea-loch. Helgoland Mar Res 30:527-545

Josselyn MN, Mathieson AC (1980) Seasonal influx and decomposition of autochthonous macrophyte litter in a north temperate estuary. Hydrobiologia 71:197-208

> Josselyn MN, Cailliet GM, Niesen TM, Cowen R, Hurley AC, Connor J, Hawes S (1983) Composition, export and faunal utilization of drift vegetation in the Salt River submarine canyon. Estuar Coast Shelf Sci 17:447-465

Kaehler S, Pakhomov EA, Kalin RM, Davis S (2006) Trophic importance of kelp-derived suspended particulate matter in a through-flow sub-Antarctic system. Mar Ecol Prog Ser 316:17-22

Kelly JA, Krumhansl KA, Scheibling RE (2012) Drift algae subsidies to sea urchins in low productivity habitats. Mar Ecol Prog Ser 452:145-157

Kim SL (1992) The role of drift kelp in the population ecology of a Diopatra ornate Moore (Polychaeta: Onuphidae) ecotone. J Exp Mar Biol Ecol 156:253-272
Kirkman H, Kendrick GA (1997) Ecological significance and commercial harvesting of drifting and beach-cast macroalgae and seagrasses in Australia: a review. J Appl Phycol 9:311-326

Koehl MAR, Wainwright SA (1977) Mechanical adaptations of a giant kelp. Limnol Oceanogr 22:1067-1071

> Koehl MAR, Silk WK, Liang H, Mehadevan L (2008) How kelps produce blade shapes suited to different flow regimes: a new wrinkle. Integr Comp Biol 48:834-851

Konar B, Estes JA (2003) The stability of boundary regions between kelp beds and deforested areas. Ecology 84: 174-185

Koop K, Field JG (1980) The influence of food availability on the population dynamics of a supralittoral isopod Ligila dilatata Brandt. J Exp Mar Biol Ecol 48:61-72

Koop K, Griffiths CL (1982) The relative significance of bacteria, meio- and macrofauna on an exposed sandy beach. Mar Biol 66:295-300

Koop K, Newell RC, Lucas MI (1982) Microbial regeneration of nutrients from the decomposition of macrophyte debris on the shore. Mar Ecol Prog Ser 9:91-96

Kotta JT, Paalme T, Puss K, Herkul K, Kotta I (2008) Contribution of scale-dependent environmental variability on the biomass patterns of drift algae and associated invertebrates in the Gulf of Riga, northern Baltic Sea. J Mar Syst 74:S116-S123

Kowalski JL, DeYoe HR, Allison TC (2009) Seasonal production and biomass of the seagrass, Halodule weightii Aschers. (shoal grass), in a subtropical Texas lagoon. Estuaries Coasts 32:467-482

Kristensen E (1994) Decomposition of macroalgae, vascular plants and sediment detritus in seawater: use of stepwise thermogravimetry. Biogeochemistry 26:1-24

Kristensen E, Bouillon S, Dittmar T, Marchand C (2008) Organic carbon dynamics in mangrove ecosystems: a review. Aquat Bot 89:201-219

Krumhansl KA, Scheibling RE (2011a) Detrital production in Nova Scotian kelp beds: patterns and processes. Mar Ecol Prog Ser 421:67-82

> Krumhansl KA, Scheibling RE (2011b) Spatal and temporal variation in grazing damage by the gastropod Lacuna vincta in Nova Scotian kelp beds. Aquat Biol 13:163-173

Krumhansl KA, Scheibling RE (2012) Detrital subsidy from subtidal kelp beds is altered by the invasive green alga Codium fragile spp. fragile. Mar Ecol Prog Ser 456: 73-85

> Krumhansl KA, Lee MJ, Scheibling RE (2011) Grazing damage and encrustation by an invasive bryozoan reduce the ability of kelps to withstand breakage by waves. J Exp Mar Biol Ecol 407:12-18

Lamberti GA, Chaloner DT, Hershey AE (2010) Linkages among aquatic ecosystems. J N Am Benthol Soc 29: 245-263

Lastra M, Page HM, Dugan JE, Hubbard DM, Rodil IF (2008) Processing of allochthonous macrophyte subsidies by sandy beach consumers: estimates of feeding rates and impacts on food resources. Mar Biol 154:163-174

Lauzon-Guay JS, Scheibling RE (2007) Seasonal variation in movement, aggregation and destructive grazing of the sea urchin (Strongylocentrotus droebachiensis) in relation to wave action and sea temperature. Mar Biol 151: 2109-2118

Lavoie DR (1985) Population dynamics and ecology of beach wrack macroinvertebrates of the central California coast. Bull S Calif Acad Sci 84:1-22 
Lee KH, Moran MA, Benner R, Hodson RE (1990) Influence of soluble components of red mangrove (Rhizophora mangle) leaves on microbial decomposition of structural (lignocellulosic) leaf components in seawater. Bull Mar Sci 46:374-386

Lenanton RCJ, Robertson AI, Hansen JA (1982) Nearshore accumulations of detached macrophytes as nursery areas for fish. Mar Ecol Prog Ser 9:51-57

Levin LA, Smith CR (1984) Response of background fauna to disturbance and enrichment in the deep sea: a sediment tray experiment. Deep-Sea Res 31:1277-1285

Loreau M, Mouquet N, Holt RD (2003) Meta-ecosystems: a theoretical framework for a spatial ecosystem ecology. Ecol Lett 6:673-679

> Lorentsen SH, Sjotun K, Gremillet D (2010) Multi-trophic consequences of kelp harvest. Biol Conserv 143: 2054-2062

> Lotze HK, Lenihan HS, Nourque BJ, Bradbury RH and others (2006) Depletion, degradation, and recovery potential of estuaries and coastal seas. Science 312:1806-1809

Lugo AE, Snedaker SC (1975) Properties of mangrove forests in southern Florida. In: Walsh GE, Snedaker SC, Teas HJ (eds) Proc Int Symp Biol Manage Mangroves. Institute of Food and Agriculture Science, University of Florida, Gainsville, FL, p 170-212

> Lüning K (1979) Growth strategies of three Laminaria species (Phaeophyceae) inhabiting different depth zones in the sublittoral region of Helgoland (North Sea). Mar Ecol Prog Ser 1:195-207

MacArthur LD, Phillips DL, Hyndes GA, Hanson CE, Vanderklift MA (2011) Habitat surrounding patch reefs influences the diet and nutrition of the western rock lobster. Mar Ecol Prog Ser 436:191-205

- Macchiavello J, Araya E, Bulboa C (2010) Production of Macrocystis pyrifera (Laminariales; Phaeophyceae) in northern Chile on spore-based culture. J Appl Phycol 22:691-697

Mach KJ, Nelson DV, Denny MW (2007) Techniques for predicting the lifetimes of wave-swept macroalgae: a primer on fracture mechanics and crack growth. J Exp Biol 210:2213-2230

> Mamouridis V, Cartes JE, Parra S, Fanelli E, Salinas JIS (2011) A temporal analysis on the dynamics of deep-sea macrofauna: influence of environmental variability off Catalonia coasts (western Mediterranean). Deep-Sea Res I 58:323-337

> Mann KH (1973) Seaweeds: their productivity and strategy for growth. Science 182:975-981

> Mann KH (1977) Destruction of kelp-beds by sea-urchins: A cyclical phenomenon or irreversible degradation? Helgoland Mar Res 30:455-467

> Mann KH (1988) Production and use of detritus in various freshwater, estuarine, and coastal marine systems. Limnol Oceanogr 33:910-930

Mann KH, Jarman NG, Dieckmann GS (1979) Development of a method for measuring the productivity of Ecklonia maxima (Osbeck). Papenf Trans R Soc S Afr 44:27-42

Marczak LB, Thompson RM, Richardson JS (2007) Metaanalysis: Trophic level, habitat, and productivity shape the food web effects of resource subsidies. Ecology 88:140-148

> Marleau JN, Guichard F, Mallard F, Loreau M (2010) Nutrient flows between ecosystems can destabilize simple food chains. J Theor Biol 266:162-174

Martinez EA, Cardenas L, Pinto R (2003) Recovery and genetic diversity of the intertidal kelp Lessonia nigres- cens (Phaeophyceae) 20 years after El Niño 1982/83. J Phycol 39:504-508

Mascaro O, Oliva S, Perez M, Romero J (2009) Spatial variability in ecological attributes of the seagrass Cymodocea nodosa. Bot Mar 52:429-438

Mateo MA, Cebrian J, Dunton K, Mutchler T (2006) Carbon flux in seagrass ecosystems. In: Larkum AWD, Orth RJ, Duarte C (eds) Seagrasses: biology, ecology and conservation. Springer, Dordrecht, p 159-192

Mattison JE, Trent JD, Shanks AL, Akin TB, Pearse JS (1977) Movement and feeding activity of red sea urchins (Strongylocentrotus franciscanus) adjacent to a kelp forest. Mar Biol 39:25-30

> McDevit DC, Saunders GW (2010) A DNA barcode examination of the Laminariaceae (Phaeophyceae) in Canada reveals novel biogeographical and evolutionary insights. Phycologia 49:235-248

McDonald PS, Bingham BL (2010) Comparing macroalgal food and habitat choice in sympatric, tube-building amphipods, Ampithoe lacertosa and Peramphithoe humeralis. Mar Biol 157:1513-1524

> McLachlan A (1985) The biomass of macro- and interstitial fauna on clean and wrack-covered beaches in western Australia. Estuar Coast Shelf Sci 21:587-599

> Medina M, Andrade S, Faugeron S, Lagos N, Mella D, Correa JA (2005) Biodiversity of rocky intertidal benthic communities associated with copper mine tailing discharges in northern Chile. Mar Pollut Bull 50:396-409

Mellbrand K, Lavery PS, Hyndes G, Hamback PA (2011) Linking land and sea: different pathways for marine subsidies. Ecosystems 14:732-744

Menendez M (2008) Leaf growth, senescence and decomposition of Juncus maritimus Lam. in a coastal Mediterranean marsh. Aquat Bot 89:365-371

Miller RJ (1985) Succession in sea urchin and seaweed abundance in Nova Scotia, Canada. Mar Biol 84:275-286

Miller SM, Hurd CL, Wing SR (2011) Variations in growth, erosion, productivity, and morphology of Ecklonia radiata (Alariaceae; Laminariales) along a fjord in southern New Zealand. J Phycol 47:505-516

Mokievsky VO, Filippova KA, Chesunov AV (2005) Nematode fauna associated with detached kelp accumulations in the subtidal zone of the White Sea. Oceanology (Mosc) 45:689-697

> Montemayor DI, Addino M, Fanjul E, Escapa M, Alvarez MF, Botto F, Iribarne OO (2011) Effect of dominant Spartina species on salt marsh detritus production in SW Atlantic estuaries. J Sea Res 66:104-110

Munro ALS, Wells JBJ, McIntyre AD (1978) Energy flow in the flora and meiofauna of sandy beaches. Proc R Soc Edinb 76B:297-315

Nakano S, Murakami M (2001) Reciprocal subsidies: dynamic interdependence between terrestrial and aquatic food webs. Proc Natl Acad Sci USA 98:166-170

Newell RC, Lucas MI, Velimirov B, Seiderer LJ (1980) Quantitative significance of dissolved organic losses following fragmentation of kelp (Ecklonia maxima and Laminaria pallida). Mar Ecol Prog Ser 2:45-59

Newell RC, Field JG, Griffiths CL (1982) Energy balance and significance of micro-organisms in a kelp bed community. Mar Ecol Prog Ser 8:103-113

Newell SY, Fallon RD, Cal Rodriguez RM, Groene LC (1985) Influence of rain, tidal wetting and relative humidity on release of carbon dioxide by standing-dead salt marsh plants. Oecologia 68:73-79 
Norderhaug KM, Fredriksen S, Nygaard K (2003) Trophic importance of Laminaria hyperborea to kelp forest consumers and the importance of bacterial degradation to food quality. Mar Ecol Prog Ser 255:135-144

> Nordhaus I, Salewski T, Jennerjahn TC (2011) Food preferences of mangrove crabs related to leaf nitrogen compounds in the Segara Anakan Lagoon, Java, Indonesia. J Sea Res 65:414-426

> Norkko J, Bonsdorf E, Norkko A (2000) Drifting algal mats as an alternative habitat for benthic invertebrates: species specific responses to a transient resource. J Exp Mar Biol Ecol 248:79-104

> Norton TA, Fetter R (1981) The settlement of Sargassum muticum propagules in stationary and flowing water. J Mar Biol Assoc UK 61:929-940

> Novaczek I (1984) Development and phenology of Ecklonia radiata at two depths in Goat Island Bay, New Zealand. Mar Biol 81:189-197

Okey TA (1997) Sediment fishing observations, earthquake slumping, and benthic community changes in Monterey Canyon head. Cont Shelf Res 17:877-897

> Okey TA (2003) Macrobenthic colonist guilds and renegades in Monterey Canyon (USA) drift algae: partitioning multidimensions. Ecol Monogr 73:415-440

> Orr M, Zimmer M, Jelinski DE, Mews M (2005) Wrack deposition on different beach types: spatial and temporal variation in the pattern of subsidy. Ecology 86: 1496-1507

Papadimitriou S, Kennedy H, Kennedy DP, Borum J (2005) Seasonal and spatial variation in the organic carbon and nitrogen concentration and their stable isotopic composition in Zostera marina (Denmark). Limnol Oceanogr 50: 1084-1095

Pearse AS, Humm HJ, Wharton GW (1942) Ecology of sand beaches at Beaufort, NC. Ecol Monogr 12:135-190

> Pedersen MF, Staehr PA, Wernberg T, Thomsen MS (2005) Biomass dynamics of exotic Sargassum muticum and native Halidrys siliquosa in Limfjorden, Denmark - implications of species replacements on turnover rates. Aquat Bot 83:31-47

$>$ Peteiro C, Freire O (2011) Offshore cultivation methods affects blade features of the edible seaweed Saccharina latissima in a bay of Galicia, Northwest Spain. Russ J Mar Biol 37:319-323

> Piriz ML, Eyras MC, Rostagno CM (2003) Changes in biomass and botanical composition of beach-cast seaweeds in a disturbed coastal area from Argentine Patagonia. J Appl Phycol 15:67-74

Polis GA, Hurd SD (1996) Linking marine and terrestrial food webs: Allochthonous input from the ocean supports high secondary productivity on small islands and coastal land communities. Am Nat 147:396-423

> Polis GA, Anderson WB, Holt RD (1997) Toward an integration of landscape and food web ecology: the dynamics of spatially subsidized food webs. Annu Rev Ecol Syst 28: 289-316

Poovachiranon S, Boto K, Duke N (1986) Food preference studies and ingestion rate measurements of the mangrove amphipod Parhyale hawaiensis (Dana). J Exp Mar Biol Ecol 98:129-140

> Prado P, Heck KL (2011) Seagrass selection by omnivorous and herbivorous consumers: determining factors. Mar Ecol Prog Ser 429:45-55

$>$ Pulfrich A, Parkins CA, Branch GM (2003) The effects of shore-based diamond-diving on intertidal and subtidal biological communities and rock lobsters in southern Namibia. Aquat Conserv 13:233-255

Radiarta IN, Saitoh SI, Yasui H (2011) Aquaculture site selection for Japanese kelp (Laminaria japonica) in southern Hokkaido, Japan, using satellite remote sensing and GIS-based models. ICES J Mar Sci 68:773-780

Ragan MA, Glombitza KW (1986) Phlorotannins, brown algal phenols. In: Round FE, Chapman DJ (eds) Progress in phycological research. Vol 4. Biopress, Bristol, p 129-241

Rao RG, Woitchik AF, Goeyens L, Vanriet A, Kazungu J, Dehairs F (1994) Carbon, nitrogen contents and stable carbon-isotope abundance in mangrove leaves from an east-African coastal lagoon (Kenya). Aquat Bot 47: 175-183

Reed DC, Rassweiler A, Arkema KK (2008) Biomass rather than growth rate determines variation in net primary production by giant kelp. Ecology 89:2493-2505

Robertson AI (1988) Decomposition of mangrove leaf litter in tropical Australia. J Exp Mar Biol Ecol 116:235-247

> Rodriguez SR (2003) Consumption of drift kelp by intertidal populations of the sea urchin Tetrapygus niger on the central Chilean coast: possible consequences at different ecological levels. Mar Ecol Prog Ser 251:141-151

Rodriguez SR, Farina JM (2001) Effect of drift kelp on the spatial distribution pattern of the sea urchin Tetrapygus niger: a geostatistical approach. J Mar Biol Assoc UK 81:179-180

Rogers-Bennett L, Bennett WA, Fastenau HC, Dewees CM (1995) Spatial variation in red sea urchin reproduction and morphology: implications for harvest refugia. Ecol Appl 5:1171-1180

> Rothausler E, Gomez I, Hinojosa IA, Karsten U, Tala F, Thiel M (2009) Effect of temperature and grazing on growth and reproduction of floating Macrocystis spp. (Phaeophyceae) along a latitudinal gradient. J Phycol 45: 547-559

> Rothausler E, Gomez I, Karsten U, Tala F, Thiel M (2011a) Physiological acclimation of floating Macrocystis pyrifera to temperature and irradiance ensures long-term persistence at the sea surface at mid-latitudes. J Exp Mar Biol Ecol 405:33-41

> Rothausler E, Gomez I, Karsten U, Tala F, Thiel M (2011b) UV-radiation versus grazing pressure: Long-term floating of kelp rafts (Macrocystis pyrifera) is facilitated by efficient photoacclimation but undermined by grazing losses. Mar Biol 158:127-141

> Rothman MD, Anderson RJ, Smit AJ (2006) The effects of harvesting of the South African kelp (Ecklonia radiata) on the kelp population structure, growth rate and recruitment. J Appl Phycol 18:335-341

> Sanmarti N, Menendex M (2007) Litter decomposition of Scirpus maritimus L. in a Mediterranean coastal marsh: importance of the meiofauna during initial phases of detached leaves decomposition. Int Rev Hydrobiol 92: 211-226

Sauchyn LK, Scheibling RE (2009a) Fecal production by sea urchins in native and invaded algal beds. Mar Ecol Prog Ser 396:35-48

> Sauchyn LK, Scheibling RE (2009b) Degradation of sea urchin feces in a rocky subtidal ecosystem: implications for nutrient cycling and energy flow. Aquat Biol 6:99-108

> Sauchyn LK, Lauzon-Guay JS, Scheibling RE (2011) Sea urchin fecal production and accumulation in a rocky subtidal ecosystem. Aquat Biol 13:215-223 
Schaal G, Riera P, Leroux C (2009) Trophic significance of the kelp Laminaria digitata (Lamour.) for the associated food web: a between-sites comparison. Estuar Coast Shelf Sci 85:565-572

Schaal G, Riera P, Leroux C (2010) Trophic ecology in a Northern Brittany (Batz Island, France) kelp (Laminaria digitata) forest, as investigated through stable isotopes and chemical assays. J Sea Res 63:24-35

Scheibling RE, Gagnon P (2009) Outbreak dynamics of an invasive bryozoan Membranipora membranacea in Nova Scotian kelp beds. Mar Ecol Prog Ser 390:1-13

Scheibling RE, Raymond BG (1990) Community dynamics on a subtidal cobble bed following mass mortalities of sea urchins. Mar Ecol Prog Ser 63:127-145

Scheibling RE, Hennigar AW, Balch T (1999) Destructive grazing, epiphytism, and disease: the dynamics of sea urchin-kelp interactions in Nova Scotia. Can J Fish Aquat Sci 56:2300-2314

Sears ALW, Holt RD, Polis GA (2004) Feast and famine in food webs: the effects of pulsed productivity. In: Polis GA, Power ME, Huxel GA (eds) Food webs at the landscape level. University of Chicago Press, Chicago, IL, p 424-451

Seymour RJ, Tegner MJ, Dayton PK, Parnell PE (1989) Storm wave induced mortality of giant kelp, Macrocystis pyrifera, in southern California. Estuar Coast Shelf Sci 28:277-292

> Sharp G, Allard M, Lewis A, Semple R, Rocheford G (2008) The potential for seaweed resource development in subarctic Canada; Nunavik, Ungava Bay. J Appl Phycol 20: 491-498

Shi J, Wei H, Zhao L, Yuan Y, Fang J, Zhang J (2011) A physical-biological coupled aquaculture model for a suspended aquaculture area of China. Aquaculture 318: 412-424

Siddon CE, Witman JD (2003) Influence of chronic, low-level hydrodynamic forces on subtidal community structure. Mar Ecol Prog Ser 261:99-110

Simoes MP, Calado ML, Madeira M, Gazarini LC (2011) Decomposition and nutrient release in halophytes of a Mediterranean salt marsh. Aquat Bot 94:119-126

Skov MW, Hartnoll RG (2002) Paradoxical selective feeding on a low-nutrient diet: Why do mangrove crabs eat leaves? Oecologia 131:1-7

Smit AJ, Brearley A, Hyndes GA, Lavery PS, Walker DI (2006) $\delta^{15} \mathrm{~N}$ and $\delta^{13} \mathrm{C}$ analysis of a Posidonia sinuosa seagrass bed. Aquat Bot 84:277-282

Smith DR (1983) Enrichment, disturbance and deep-sea community structure: the significance of large organic falls to bathyal benthos in Santa Catalina Basin. PhD dissertation, University of California, San Diego

Smith BD, Foreman RE (1984) An assessment of seaweed decomposition within a southern Strait of Georgia seaweed community. Mar Biol 84:197-205

Soares AG, McLachlan A, Schlacher TA (1996) Disturbance effect of stranded kelp on populations of the sandy beach bivalve Donax serra (Roding). J Exp Mar Biol Ecol 205: 165-186

Spiller DA, Piova-Scott J, Wright AN, Yang LH, Takimoto G, Schoener TW, Iwata T (2010) Marine subsidies have multiple effects on coastal food webs. Ecology 91:1424-1434

Springer YP, Hays CG, Carr MH, Mackey MR (2010) Toward ecosystem-based management of marine macroalgae- the bull kelp, Nereocystis luetkeana. Oceanogr Mar Biol Annu Rev 48:1-42
Stahlberg C, Bastviken D, Svensson BH, Rahm L (2006) Mineralisation of organic matter in coastal sediments at different frequency and duration of resuspension. Estuar Coast Shelf Sci 70:317-325

Steneck RS, Graham MH, Bourque BJ, Corbett D, Erlandson JM, Estes JA, Tegner MJ (2002) Kelp forest ecosystems: biodiversity, stability, resilience and future. Environ Conserv 29:436-459

Stenton-Dozey JME, Griffiths CL (1983) The fauna associated with kelp stranded on a sandy beach. In: McLachlan N, Erasmus T (eds) Sandy beaches as ecosystems. W. Junk Publisher, The Hague, p 557-568

Stephenson RL, Tan FC, Mann KH (1986) Use of stable carbon isotope ratios to compare plant material and potential consumers in a seagrass bed and a kelp bed in Nova Scotia, Canada. Mar Ecol Prog Ser 30:1-7

Tala F, Edding M (2007) First estimates of productivity in Lessonia trabeculata and Lessonia nigrescens (Phaeophyceae, Laminariales) from the southeast Pacific. Phycol Res 55:66-79

Tallis H (2009) Kelp and rivers subsidize rocky intertidal communities in the Pacific Northwest (USA). Mar Ecol Prog Ser 389:85-96

Tenore KR, Hanson RB, McClain J, Maccubbin AE, Hodson RE (1984) Changes in composition and nutritional value to a benthic deposit feeder of decomposing detritus pools. Bull Mar Sci 35:299-311

Thiel M, Gutow L (2005) The ecology of rafting in the marine environment. II. The rafting organisms and community. Oceanogr Mar Biol Annu Rev 43:279-418

> Thompson SA, Knoll H, Blanchette CA, Nielsen KJ (2010) Population consequences of biomass loss due to commercial collection of the wild seaweed Postelisa palmaeformis. Mar Ecol Prog Ser 413:17-31

> Thomsen MA, Wernberg T (2005) Miniview: What affects the forces required to break or dislodge macroalgae? Eur J Phycol 40:139-148

> Thongtham N, Kristensen E (2005) Carbon and nitrogen balance of leaf-eating sesarmid crabs (Neoepisesarma versicolor) offered different food sources. Estuar Coast Shelf Sci 65:213-222

Thrush SF (1986) The sublittoral macrobenthic community structure of an Irish sea-lough: effect of decomposing accumulations of seaweed. J Exp Mar Biol Ecol 96: 199-212

Touchette BW, Burkeholder JM, Glasgow HB (2003) Variations in eelgrass (Zostera marina L.) morphology and internal nutrient composition as influenced by increased temperature and water column nitrate. Estuaries 26: $142-155$

> Troell M, Robertson-Andersson D, Anderson RJ, Bolton JJ, Maneveldt G, Halling C, Probyn T (2006) Abalone farming in South Africa: An overview with perspectives on kelp resources, abalone feed, potential for on-farm seaweed production and socio-economic importance. Aquaculture 257:266-281

> Tutschulte TC, Connell JH (1988) Feeding behavior and algal food of three species of abalones (Haliotis) in southern California. Mar Ecol Prog Ser 49:57-64

Tzetlin AB, Mokievsky VO, Melnikov AN, Saphonov MV, Simdyanov TG, Ivanov IE (1997) Fauna associated with detached kelp in different types of subtidal habitats of the White Sea. Hydrobiologia 355:91-100

$>$ Utter BD, Denny MW (1996) Wave-induced forces on the giant kelp Macrocystis pyrifera (Agardh): field test of a computational model. J Exp Biol 199:2645-2654 
Van Alstyne KL, Whitman SL, Ehlig JM (2001) Differences in herbivore preferences, phlorotannin production, and nutritional quality between juvenile and adult tissues from marine brown algae. Mar Biol 139:201-210

- Van Tussenbroek BI (1993) Plant and frond dynamics of the giant kelp, Macrocystis pyrifera, forming a fringing zone in the Falkland Islands. Eur J Phycol 28:161-165

> Vanderklift MA, Kendrick GA (2005) Contrasting influence of sea urchins on attached and drift macroalgae. Mar Ecol Prog Ser 299:101-110

Vanderklift MA, Wernberg T (2008) Detached kelps from distant sources are a food subsidy for sea urchins. Oeceologia 157:327-335

Vasquez JA (2008) Production, use and fate of Chilean brown seaweeds: re-sources for a sustainable fishery. J Appl Phycol 20:457-467

> Vasquez JA, Vega JMA, Buschmann AH (2006) Long term studies on El Niño-La Niña in northern Chile: effects on the structure and organization of subtidal kelp assemblages. J Appl Phycol 18:505-519

Vea J, Ask E (2011) Creating a sustainable commercial harvest of Laminaria hyperborea in Norway. J Appl Phycol 23:489-494

Velimirov B, Griffiths CL (1979) Wave-induced kelp movement and its importance for community structure. Bot Mar 22:169-172

Vetter EW (1995) Detritus-based patches of high secondary production in the nearshore benthos. Mar Ecol Prog Ser 120:251-262

$>$ Vetter EW (1996) Enrichment experiments and infaunal population cycles on a southern California sand plain: response of the leptostracan Nebalia daytoni and other infauna. Mar Ecol Prog Ser 137:83-93

Vetter EW (1998) Population dynamics of a dense assemblage of marine detritivores. J Exp Mar Biol Ecol 226: 131-161

Vetter EW, Dayton PK (1998) Macrofaunal communities within and adjacent to a detritus-rich submarine canyon system. Deep-Sea Res II 45:25-54

> Vetter EW, Dayton PK (1999) Organic enrichment by macrophyte detritus, and abundance patterns of megafaunal

Editorial responsibility: Kenneth Heck Jr., Dauphin Island, Alabama, USA populations in submarine canyons. Mar Ecol Prog Ser 186:137-148

> Vinther HF, Laursen JS, Holmer M (2008) Negative effects of a blue mussel (Mytilus edulis) presence in eelgrass (Zostera marina) beds in Flensbord fiord, Denmark. Estuar Coast Shelf Sci 77:91-103

> Wakefield RL, Murray SN (1998) Factors influencing food choice by the seaweed-eating marine snail Norrisia norrisi (Trochidae). Mar Biol 130:631-642

- Watanabe S, Metaxas A, Scheibling RE (2009) Dispersal potential of the invasive green alga Codium fragile ssp. fragile. J Exp Mar Biol Ecol 381:114-125

- Wernberg T, Vanderklift MA (2010) Contribution of temporal and spatial components to morphological variation in the kelp Ecklonia (Laminariales). J Phycol 46:153-161

- Wernberg T, Vanderklift MA, How J, Lavery PS (2006) Export of detached macroalgae from reefs to adjacent seagrass beds. Oecologia 147:692-701

Wernberg T, Thomsen MS, Tuya F, Kendrick GA, Staehr PA, Toohey BD (2010) Decreasing resilience of kelp beds along a latitudinal temperature gradient: potential implications for a warmer future. Ecol Lett 13:685-694

> Witman JD (1987) Subtidal coexistence: storms, grazing, mutualism, and the zonation of kelps and mussels. Ecol Monogr 57:167-187

Witman JD, Ellis JC, Anderson WB (2004) The influence of physical processes, organisms, and permeability on cross-ecosystem fluxes. In: Polis GA, Power ME, Huxel GA (eds) Food webs at the landscape level. University of Chicago Press, Chicago, IL, p 424-451

Worm B, Sandow M, Oschlies A, Lotze HK, Myers RA (2005) Global patterns of predator diversity in the open oceans. Science 309:1365-1369

Yatsuya K, Nishigaki T, Douke A, Wada Y (2007) Seasonal changes in biomass of macrophytes stranded on Yoro Beach along a sargassacean forest in Wakasa Bay, Sea of Japan. Fish Sci 73:609-614

Yoshikawa T, Takeuchi I, Furuya K (2001) Active erosion of Undaria pinnatifida Suringar (Laminariales, Phaeophyceae) mass-cultured in Ostuchi Bay in northeastern Japan. J Exp Mar Biol Ecol 266:51-65

Submitted: January 27, 2012; Accepted: July 12, 2012 Proofs received from author(s): October 8, 2012 